UDK 323+316.4(1-664)(496.5)

Biblid 0543-3657, 72 (2021)

God. LXXII, br. 1182, str. 33-63

Izvorni naučni rad

Primljen: 28.5.2021.

Prihvaćen: 18.6.2021.

doi: https://doi.org/10.18485/iipe_mp.2021.72.1182.2

Stefan BOŠKOVIĆ ${ }^{1}$

\title{
Ska shteti, ska ligj! \\ (Nema države, nema zakona!) \\ Unutrašnji politički izazovi i tranzicione poteškoće u Albaniji 1990-1997*2
}

\begin{abstract}
SAŽETAK
Istraživanje ispituje uticaj posthladnoratovskih sveprožimajućih mjera kontrole na reakciju naroda u Albaniji na urušavanje takvog sistema i njenih posledica. Takođe, neophodno je osvrnuti se na suprotstavljenost albanske narodne različitosti, istoriju podastiranja centralnih vlada i nauma komunističke vlasti u stvaranju snažne uprave i integrisane albanske nacije. Time istraživačko pitanje glasi: da li je nedostatak demokratskog iskustva kod postsocijalističkih predvodnika vlasti zajedno sa (pre)brzim društvenim promjenama, podstakao povratak albanskih narodnih razlika i osporavanje autoriteta centralnih uprava? Kvalitativne metode analize pokazuju da je potonuće izrazito rigoroznog sistema bilo praćeno krajnostima. Isto tako, hitri prelazak u ustrojstvo gdje neafirmisani predstavnici vlasti posjeduju znatno manju regulatornu ulogu, predstavlja više nego pogodno tlo za vraćanje unutrašnje narodne raznolikosti i sa njom odbacivanje načela državne organizacije.

Ključne riječi: Albanija, tranzicija, Sali Beriša, izbori, piramidalne šeme, partikularizam.
\end{abstract}

${ }^{1}$ Autor je istraživač pripravnik na Fakultetu političkih nauka, Univerziteta $\mathrm{u}$ Beogradu, kao doktorand stipendista Ministarstva prosvete, nauke i tehnološkog razvoja Republike Srbije.

${ }^{2}$ Pojedini pogledi izneti u članku odražavaju autorov lični stav, a ne institucije u kojoj je zaposlen. 
Činjenica da je Albanija bila jedina država, od budućih socijalističkih na čijoj teritoriji tokom narodnooslobodilačke borbe nije kročio nijedan sovjetski vojnik, u velikoj mjeri određivala je spoljnopolitičku i unutrašnju političku putanju države u periodu Hladnog rata. Takav tok događaja potvrdio je komunističku vlast Envera Hodže (Enver Hoxha) nakon 1944. godine i omogućio je vođenje samostalne državne spoljne politike (Tarifa 1995, 134). ${ }^{3}$ Ipak, samostalna spoljna politika dovela je do druge (oprečne) pojave - ekonomske zavisnosti Albanije u odnosu na trenutnog spoljnopolitičkog saveznika. Isprva je to bila socijalistička Jugoslavija, zatim Savez Sovjetskih Socijalističkih Republika (SSSR) i na kraju Narodna Republika Kina. ${ }^{4}$ Važno je naglasiti da skoro do kraja postojanja Narodne Republike (NR) Albanije, bilo kakva različitost mišljenja od propisane državne ideologije, nije bila dozvoljena. Albanska jedinstvenost, čak u odnosu na ostale socijalističke države, imala je još jednu svoju osobenost sadržanu u potpunoj, cjelokupnoj kontroli informacija koje su dolazile iz spoljnog svijeta. Mnogobrojne unutrašnje razlike i razvijena partikularna svijest $\mathrm{u}$ albanskom narodu, odnosno istorija podastiranja autoriteta centralnih vlasti u Albaniji tokom prve polovine XX vijeka, predstavljale su ozbiljnu smetnju (prijetnju) prioritetima komunističke vlasti sadržanim u stvaranju jake centralne uprave i dubinski integrisane albanske nacije.

Uprkos tome, ekonomski razvoj u NR Albaniji tokom 60-ih i 70-ih godina, najviše zbog inostrane pomoći i katastrofalnog stanja u državi nakon Drugog svjetskog rata, činio je situaciju podnošljivom. Razlazom sa poslednjim saveznikom 1978. godine i ustavom dvije godine ranije, koji je NR Albaniju u članu 37 odredio kao prvu ateističku državu u svijetu, ${ }^{5}$ samodovoljnost kao željeni pravac razvoja države, te zabranu filozofije izvan marksističko-lenjinističke, ${ }^{6}$ uklonio je perspektivu dužeg postojanja takvog sistema. Ipak, sveprožimajući državni aparat sa generalnim

${ }^{3}$ Fatos Tarifa, "Albania's Road from Communism: Political and Social Change, 19901993", Development and Change, vol. 26, no. 1, 1995, p. 134.

${ }^{4}$ Usmjerenost Albanije ka SFRJ traje do 1948. godine i rezolucije Informbiroa 28. juna te godine. Nakon zauzimanja protivnog stava prema Jugoslaviji, Albanija se okreće prema SSSR-u, koje je prisutno do potpisivanja Beogradske i Moskovske deklaracije 1955. odnosno 1956. godine. Potpisivanjem tih deklaracija, otpočinje period zahlađivanja odnosa između Albanije i SSSR, čije savezništvo nedugo potom, Albanija zamjenjuje sa NR Kinom.

${ }^{5}$ Bjoern Andersen, The Constitution of the People's Socialist Republic of Albania, 2005, Internet, http:/ / bjoerna.dk/dokumentation/Albanian-Constitution-1976.htm, 20/ $10 / 2020$.

${ }^{6}$ Fatos Tarifa “Albania's Road from Communism: Political and Social Change, 199034 1993", op. cit., p. 138. 
sekretarom onemogućio je i najmanje promjene sovjetske planskekomandne ekonomije ustanovljene u NR Albaniji nakon 1944. godine. Premda su samoizolacionizam i sveprisutnost države $u$ društvu neprestano predstavljana kao jedina sredstva za očuvanje tekovine oslobođenja i nezavisnosti albanske države, nedugo nakon smrti Envera Hodže, sveobuhvatno nezavidno stanje u državi, uticalo je na postepeno popuštanje u primjeni ovih načela.

Iako su ova načela bila djelotvorna, ista nisu mogla ostati imuna na promjene koje su se dešavale u Evropi tokom 1989. i 1990. godine. Takođe, važno je naglasiti da je njihova dugotrajnost i ostavljeno „nasleđe“ proizvelo izrazitiju reakciju naroda u Albaniji i podvajanje istog, nego u drugim bivšim socijalističkim državama. Pored zastrašujućih poteškoća koje je albanski narod iskusio između 1990. i 1992. godine, višedecenijska komunistička uprava stvorila je privremeno rasprostranjen antikomunistički narativ u društvu, koji je uz bitnu međunarodnu ulogu, promjenu vlasti na izborima 1992. godine učinio lako predvidivom. Upravo je međunarodna uloga bila od velikog značaja za postizborno preoblikovanje albanskog društva. Međutim, predizborno antikomunističko jedinstvo vrlo brzo se raspršilo, a uslijedio je (pre)brz prelazak albanskog naroda iz strogo kontrolisanog ustrojstva u sistem koji je omogućavao nezamisliv stepen sloboda. ${ }^{7}$ Ipak, isti nije bio praćen adekvatnim strategijama/odgovorima vlasti na društvene izazove. Pomenute slobode su više podsjećale na mnogostruko bespravlje, što je uticalo na još veće podvajanje i međusobno otuđenje unutar albanskog društva. Sunovrat piramidalnih šema poslužio je kao idealno tlo za povratak albanske raznolikosti, a sa njima i tradicija protivrečenja autoritetu centralne vlasti.

$S$ obzirom na snagu tih narodnih razlika i partikularne svijesti $u$ osporavanju autoriteta centralnih vlasti u Albaniji, istraživačko pitanje glasi: da li je preuzimanje vlasti, u načelu, od demokratske partije, ali partije čiji su predvodnici manjkali u demokratskom iskustvu i hitro sprovedenog cjelokupnog preoblikovanja društva, uticalo da se albanske unutrašnje različitosti i odnos prema centralnoj vlasti u potpunosti povrati?

\section{Pregled literature}

Poimanje procesa demokratizacije ističe faktore koji su snažno doprinijeli pojavi i trenutku trećeg talasa tranzicije ka demokratiji. Od neposrednijeg značaja za ovu temu jesu produbljivanje problema legitimiteta vlasti autoritarnih država i uticaj prethodnih tranzicija u trećem

\footnotetext{
${ }^{7}$ Bernd J. Fischer, “Albania since 1989: The Hoxhaist Legacy”, in: Sabrina P. Ramet (ed.), Central and Southeast European Politics since 1989, Cambridge University Press, New York, 2010, p. 482.
} 
talasu, ogledan u podsticanju i pružanju okvira za naredne napore demokratizacije. ${ }^{8}$ Ipak, snagu problema legitimiteta vlasti kod svih država nekadašnjeg Istočnog bloka ${ }^{9}$ ne treba izjednačavati. Za razliku od one koja posjeduje spoljnu podršku, unutrašnja revolucionarna borba proizvodi šire javne i patriotske identitete koji održavaju autoritarne režime na nivou elita i masa. ${ }^{10} \mathrm{~S}$ tim u vezi, stvaranje i transformacija političkih identiteta ne zasniva se samo na građenju i potvrdi raznovrsnih partizanskih identiteta, već uključuje genezu ili preoblikovanje uspavanih patriotskih identiteta pred glavnom spoljnom prijetnjom. ${ }^{11}$ Tako, revolucionarni režimi koriste od "standardnih“" posledica revolucija za koheziju elita i od patriotskog legitimiteta nastalog u oslobodilačkoj borbi, koji pojačava jedinstvo elita i narodnu podršku. ${ }^{12}$ Shodno ovome, teško je da će samo prethodni procesi demokratizacije, ukoliko u jednoj državi ne postoje povoljni uslovi, dovesti do istovjetnog stanja. ${ }^{13}$ Međutim, takvi procesi mogu imati značajnu ulogu podsticanja liberalizacije autoritarnih režima. Koliko je bitna ta uloga svjedoči činjenica da autoritarni režimi ne mogu tolerisati nezavisne organizacije. ${ }^{14}$ Razlog je da dokle god ne postoje kolektivne alternative, pojedinačni stavovi građana prema režimu ne posjeduju veću važnost. ${ }^{15}$ Ipak, šta je prijeteće po autoritarne režime - nije slom legitimiteta, već organizacija suprotne "hegemonije“: kolektivnih projekata za alternativnu budućnost. ${ }^{16}$ Samo kada je kolektivna alternativa dostupna tada je politički izbor pojedincima raspoloživ, ${ }^{17}$ čime nastaje opasnost po opstanak autoritarnog režima. Izdvajaju se dva načina dobijanja građanske „privilegije“ političkog izbora. Pored unutrašnjeg procijepa autoritarnog režima, koji dovodi do nicanja nezavisnih organizacija, drugi način koji obuhvata njihov rast jeste vaninstitucionalni, budući da režim uključuje samo skupine koje odobravaju njegov smjer i koje kontrolišu ishode bilo

${ }^{8}$ Samuel P. Huntington, "Democracy's Third Wave", Journal of Democracy, vol. 2, no. 2, 1991, p. 13.

${ }^{9}$ Naznaka zbog činjenice da je NR Albanija iako komunistička država, Istočni blok napustila 1968. godine.

${ }^{10}$ Nebojša Vladisavljević, “Revolutionary Origins of Political Regimes and Trajectories of Popular Mobilization in the Late Communist Period", Nationalities Papers, vol. 47, no. 4, 2019, p. 548.

${ }^{11}$ Vidjeti: Ibid., p. 548.

${ }^{12}$ Ibid., p. 548.

${ }^{13}$ Samuel P. Huntington, "Democracy's Third Wave”, op. cit., p. 16.

${ }^{14}$ Adam Przeworski, Democracy and the market: Political and economic reforms in Eastern Europe and Latin America, Cambridge University Press, Cambridge, 1991, p. 54.

${ }^{15}$ Ibid., p. 54.

${ }^{16}$ Ibid., pp. 54-55.

$36{ }^{17}$ Ibid., p. 55. 
kog političkog procesa ex post. ${ }^{18}$ Međutim, snaga takvih režima docnije se nerijetko temelji na preemptivnom gušenju drugačijih društvenih viđenja. Ukoliko takva viđenja, njihovi nositelji uspiju prevazići „bočne udarce“, onda posjeduju izglednu šansu da započnu rastavljanje autoritarnog režima. Tu međunarodna situiranost, kakva je postojala krajem 80-ih i početkom 90ih, može imati velikog uticaja s obzirom na to da ona hrabri protestante i pritiska autoritarne režime ka uspostavi višepartizma. Ustanovljenje višepartizma praćeno je izrazitom nesigurnošću i ",osnivajućim izborima“, nakon kojih se uglavnom preuređuje dotadašnja vlast - prihvataju se novoosnovane političke partije, sastavljene od elita koje su apsorobovale energiju narodnih masa. ${ }^{19}$ Po pravilu, osnovna odlika takve vlasti jeste „cjenkanje“ između dvije strane. ${ }^{20}$ Trajanje cjenkanja, zavisiće od sposobnosti novih partija da iskoriste želju naroda za cjelovitom promjenom, odnosno odlaskom komunističkih funkcionera.

Artikulisanjem narodnog raspoloženja, države centralne i istočne Evrope nakon višedecenijskog komunizma našle su se u postupku političkih i ekonomskih reformi, usmjerenih "povratku različitosti“ $\mathrm{i}$ ",konsolidaciji demokratije “. ${ }^{21}$ Ipak, brzina demokratizacije nije se odnosila isključivo na želje građana za demokratskim društvom, već i na ohrabrenja i inostrane pritiske koji su postavili demokratiju kao izričit uslov približavanja bivših socijalističkih država zapadnim integracijama. ${ }^{22}$ Opet, $\mathrm{u}$ tom procesu demokratija i prosperitet bili su daleko od pojmova zajedničkih za bivše socijalističke države. ${ }^{23}$ Šire posmatrajući, pokazatelji ekonomskog i političkog razvoja bili su naročito heterogeni. ${ }^{24}$ Dok su određene države bile uspješne u održavanju zamaha reformi nastavljajući isti, druge su iskusile ponovno pojavljivanje autoritarnih režima. ${ }^{25}$ Premda su demokratske falinke bile primjetne, značajnu ulogu političkog održavanja takvih sistema imao je Međunarodni monetarni fond (MMF) kroz "pozajmljivanje legitimiteta", ${ }^{26}$ sa cijenom odlučnog raskidanja sa socijalističkim

${ }^{18}$ Ibid., p. 59.

${ }^{19}$ Helga A. Welsh, "Political Transition Processes in Central and Eastern Europe", Comparative Politics, vol. 26, no. 4, 1994, pp. 381-382.

${ }^{20}$ Ibid., p. 382.

${ }^{21}$ Dejan Jović, "Problems of early post-communist transition theory: from transition from to transition to", Politička misao časopis za politologiju, vol. 47, no. 5, 2010, p. 45.

${ }^{22}$ Jan Fidrmuc, Economic reform, democracy and growth during post-communist transition, 2001, Internet, https://core.ac.uk/download/pdf/7056986.pdf, 04/01/2021, p. 5.

${ }^{23}$ Ibid., p. 5.

${ }^{24}$ Ibid., p. 5.

${ }^{25}$ Ibid., p. 5.

${ }^{26}$ Randall W. Stone, Lending credibility: The International Monetary Fund and the postcommunist transition, Princeton University Press, Princeton, 2012, p. 20. 
institucijama državnih subvencija i pomoći građanima. Ispostavilo se da je jedna od najvećih grešaka prvih godina tranzicije potcjenjivanje važnosti snažne države u konsolidaciji liberalne demokratije, čak i izjednačavanje smanjenja moći države sa rastom demokratije. ${ }^{27}$ Ipak posesivnim (možda i paranoičnim) čuvanjem državnih nadležnosti za sebe, izabrane političke partije (njihovi čelnici) u pojedinim postkomunističkim državama, odbacile su neizostavan činilac efikasne demokratije - robusno političko takmičenje. ${ }^{28}$ Suočeni sa ekonomskim i političkim tekovinama svog mandata, iste su se našle $u$ veoma suženom manevarskom prostoru $u$ smislu društvenog povezivanja, gdje je (pre)često naglašavana (nerealna) opasnost od povratka komunizma. ${ }^{29}$ Iz toga se može označiti kasniji uticaj represivne komunističke vladavine u državama, ${ }^{30}$ pred kojima su upravo zbog toga postojale ozbiljne prepreke ka demokratizaciji. Naravno, jedna od osnovnih razlika između ta dva razdoblja, jeste (gotovo) svestran monopol komunističke vlasti naspram one koja je naslijedila, ali koja nije ostala bez pokušaja ostvarivanja približno istog.

\section{Postepenost kao pristup promjenama u (NR) Albaniji 1990-1992}

Hodžin naslednik Ramiz Alija (Ramiz Alia), inicijalno je namjeravao da $u$ potpunosti bude odan postulatima vlasti njegovog prethodnika. Međutim, sam Alija brzo uviđa da bi samoizolacionizam i samodovoljnost dovele ekonomiju na ivicu ambisa, koji su u stvari bili prijetnja za slobodu i nezavisnost države. ${ }^{31}$ Stoga su početkom 1986. godine učinjeni prvi koraci na međunarodnom planu mali, za Albaniju posebno veliki, sadržani u pokušaju izlaska države iz samoizolacije i opreznom usmjeravanju prema zapadu. Ti koraci su nešto kasnije rezultirali uspostavljanjem diplomatskih odnosa sa nekolicinom zapadnih država, zatim uzdizanjem nivoa diplomatskog predstavljanja države u pojedinim članicama Istočnog bloka. ${ }^{32}$ Prethodno je praćeno izjavama Alije o spremnosti NR Albanije za

${ }^{27}$ Grzegorz Ekiert, Jan Kubik \& Milada Anna Vachudova, “Democracy in the PostCommunist World: An Unending Quest?", East European Politics and Societies, vol. 21, no. 1, 2007, p. 15.

${ }^{28}$ Ibid., p. 16.

${ }^{29}$ Vidjeti: Blendi Kajsiu, "Down with Politics! The Crisis of Representation in PostCommunist Albania", East European Politics and Societies, vol. 24, no. 5, 2010, pp. 237-239.

${ }^{30}$ Vidjeti: Grzegorz Ekiert, Jan Kubik \& Milada Anna Vachudova, "Democracy in the Post-Communist World: An Unending Quest?", op. cit., p. 14.

${ }^{31}$ Ramiz Alia, Une, Ramiz AIia deshmoj per historine, Zeri, Priština, 1992, p. 134.

${ }^{32}$ U pitanju su Kanada, Savezna Republika Njemačka i Španija odnosno Bugarska,

38 Demokratska Republika Njemačka, Čehoslovačka i Mađarska. 
ustanovljenje odnosa sa Sjedinjenim Američkim Državama (SAD) i SSSR-om i premijera Adila Carcanija (Adil Çarçani) o odluci državnog vođstva za prekid bojkota Konferencije za evropsku bezbjednost i saradnju ${ }^{33}$ (KEBS) i potpisivanju Helsinške povelje. ${ }^{34}$ Date izjave povlačile su višestruke obaveze za tadašnje državno rukovodstvo omogućavanja pravne odbrane na suđenjima, prava žalbe, raspodjele religijskog sadržaja, vršenja religijskih službi i dozvole stanovništvu za dobijanje pasoša, odnosno za putovanje izvan granica Albanije. ${ }^{35}$ Uporedo sa prethodnim, tokom prve polovine 1990. godine donijete su raznovrsne ekonomske regulative u cilju djelimičnog uvođenja tržišnog sistema u NR Albaniji. Ovim mjeramazakonima, usmjereni ka većim slobodama u kretanju cijena, preduzećima i bankama u upražnjavanju privatnih aktivnosti, nastojao se podstaći razvoj jednog autarhičnog, ali izrazito krhkog ekonomskog sistema, kakav je postojao u NR Albaniji. Premda su ove, za Albaniju opet, upečatljive promjene, moglo bi se reći da su one bile sredstvo trenutnog zadovoljenja stanovništva, čime bi se u nadolazećim godinama nastavila neometana uprava Partije rada Albanije. Odnosno, da su iste bile samo odgovor na postepeno "oslobađanje“ građana od državne sveprisutnosti usled međunarodne situiranosti tog vremena i da one u najvećem dijelu nisu predstavljale temelj za preoblikovanje Partije rada u posthladnoratovskim vremenima. Ipak, u onome što će uslijediti velikog udjela ima: drastičnost (ekonomske) situacije u NR Albaniji i pored pokrenutih reformi, višedecenijsko svojevrsno ophođenje komunističke uprave prema neistomišljenicima i nedostatak demokratske tradicije u Albaniji.

Ranije iznijeti zahtjevi intelektualnog dijela društva za demokratizacijom NR Albanije, najviše ka ukidanju ustava iz 1976. godine, ${ }^{36}$ odbačeni su od strane tadašnje vlasti i Alije, pravdajući takvu odluku nedostatkom podrške među stanovništvom. Proces promjena u Albaniji iz zapaženog dijela društva sagledavan je kao previše spor, dok je iz ugla tvrdokornih djelova Partije rada isti tumačen kao izvor opasnosti za tekovine Narodne Republike. Sjedinjavanje nedostatka demokratske tradicije u NR Albaniji i ekonomskih poteškoća u državi, uticali su na preovladavanje osjećanja napetosti iz kojeg je proizašlo narodno nezadovoljstvo tokom 1990. godine.

${ }^{33}$ U julu 1990. godine NR Albanija dobila je status posmatrača unutar Konferencije.

${ }^{34}$ Fatos Tarifa, "Albania's Road from Communism: Political and Social Change, 19901993 ", op. cit., p. 140.

${ }^{35}$ Ibid., p. 140.

${ }^{36}$ Ukidanje ustava iz 1976. godine podrazumijevalo je uspostavu višepartijskog sistema, vladavinu prava umjesto policijske nadmoći, potpunu obnovu slobode vjeroispovijesti i slobode mišljenja, slobodu okupljanja - stvaranje novog demokratskog okvira, suštinskog za demokratski, ekonomski i socijalni napredak i stvaranje novog ustrojstva institucija. Vidjeti: Ibid., p. 141. 
Nakon prvih znakova otpora, primjetnih u Skadru, kulminacija duže napetosti u zemlji događa se u julu 1990. godine, na antivladinim protestima u Tirani. S obzirom na to da je odgovor vlade na više desetina hiljada protestanata u središtu grada bila upotreba policijske sile, ono što je uslijedilo učinilo je dalje trajanje jednopartizma u NR Albaniji iluzornim, a začetke ove nesvakidašnje demokratizacije neminovnim. Odlučujući događaji bili su „napadi na ambasade ${ }^{\text {“ }}{ }^{37}$ Povlačeći se pred policijskim nastupima, protestanti su se ustremili ka inostranim ambasadama tražeći azil. Takav scenario potvrdio je nešto raniju odluku KEBS-a da se NR Albanija, bez ispunjavanja minimuma ljudskih prava i višepartijskog političkog sistema, ne može nadati članstvu i izlasku iz međunarodne izolacije. Uprkos tome što je Partija rada posle ovih demonstracija i dalje bila na pozicijama vlasti, činilo se da je okončanje jednopartijske uprave pitanje trenutka. U međuvremenu, prethodno dozvoljavanje postojanja ",nezavisnih političkih organizacija“, još jedno obilježje ustava iz 1976. godine uklonjeno je novembra 1990. godine zabrana upražnjavanja slobode vjeroispovijesti. ${ }^{38}$ Noseću snagu protesta decembra 1990. godine činili su, uostalom kao u svim drugim istočnim i centralnoistočnim evropskim državama - studenti i omladina. Prvenstveno, njihovi zahtjevi bili su poboljšavanje uslova $\mathrm{u}$ domovima da bi, priključivanjem intelektualnog sloja društva ${ }^{39}$ i drugih uskoro opozicionih predvodnika, protesti dobili karakter reformskog pokreta. ${ }^{40}$ Prinuđen beskompromisnim stavom studenskih protestanata o partijskoj slobodi, Alija je ispunio predate zahtjeve. Time je period partijske jedinstvenosti u Albaniji posle 45 godina završen. Međutim, samo društvo i država su zbog nezavidnog političkog ugleda buduće vlasti, zatim istovjetnog ekonomskog i socijalnog stanja postavljeni pred velike izazove koji će imati zabrinjavajuće posledice po albanski narod.

${ }^{37}$ "Napadi - okupacija ambasada" predstavlja prvi talas iseljavanja iz Albanije. Procjene su da je tokom pomenutog događaja 1990. godine, čak pet hiljada građana zatražilo azil pretežno u ambasadama Italije, Francuske i Zapadne Njemačke. Time su zahtjevi postali osnova za dalje iseljavanje iz države, koje se nastavilo i kroz luku Drač u cilju plovidbe prema Italiji, a to je nešto što će u nadolazećem periodu dobiti dramatičnu uzlaznu putanju. Vidjeti: Julie Vullnetari, Albania on the Move, Links between Internal and International Migration, Amsterdam University Press, Amsterdam, 2012, p. 67.

${ }^{38}$ Arolda Elbasani, Religion and Democratization in Post-Communist Albania: Is it Possible to Be Islamic, Democratic and European at the Same Time?, 2010, Internet, https://www.researchgate.net/publication/228161084_Religion_and_Democratiza tion_in_PostCommunist_Albania_Is_it_Possible_to_Be_Islamic_Democratic_and_E uropean_at_the_Same_Time, 27/10/2020, p. 4.

${ }^{39}$ Među intelektualcima koji su podržali proteste bio je i Ismail Kadare, koji je prethodno dobio azil u Francuskoj.

${ }^{40}$ Fatos Tarifa, "Albania's Road from Communism: Political and Social Change, 1990401993 ", op. cit., p. 145. 
Odmah po zakonskoj uspostavi partijskog pluralizma u Albaniji, osnovana je druga politička partija u Albaniji - Demokratska partija. Strukturu ove partije predstavljalo je mnoštvo različitih društvenih grupacija, povezanih posmatranjem komunističke uprave u državi isključivo kao retrogradnom pojavom. U skladu s tim, Partija i njeni predvodnici, osnivači Sali Beriša (Sali Berisha) i Gramoz Paško (Gramoz Pash ko) ${ }_{1}^{41}$ insistirali su na održavanju prvih demokratskih parlamentarnih izbora u Albaniji. Tek osnovana, Demokratska partija ostvarila je dosta dobar rezultat na izborima održanim u martu 1991. godine, osvojivši preko sedam stotina hiljada glasova. Uprkos ovom rezultatu nije bilo realno očekivati da novostvorena opoziciona partija pobjedi na izborima, pa je zato Albanska partija rada samostalno formirala vladu sa premijerom Fatosom Nanom. Iako u poziciji vlasti, Nano i njegova vlada nisu bili u mogućnosti da mnogo toga učine. Pored opstrukcije $u$ parlamentu od strane Demokratske partije, Nanova vlada suočila se sa neprekidnim štrajkovima, poput onog koji je trajao tri nedelje u Tirani i koji je bio opšteg karaktera, zatim izostankom saradnje sa sindikatima i sveopštim osjećajem ekonomske nesigurnosti koji je preovladao među stanovništvom, a iz kojeg su proizilazila masovna iseljavanja Albanaca u susjedne države. ${ }^{42}$

Nedugo nakon "napada na ambasade“, često zanemarivan događaj povodom iseljavanja iz (NR) Albanije uslijedio je krajem decembra 1990. godine. Tada je više hiljada ljudi uspjelo ilegalno da pređe planinsku granicu sa Grčkom. ${ }^{43}$ Nastavkom iseljavanja procjene su ukazivale da je do februara, odnosno marta 1991. godine, Albaniju napustilo oko 20.000 ljudi. Tada, ionako nestabilna situacija dobija dramatičan karakter. Uporedo sa

${ }^{41}$ Za napomenuti je da su Beriša i Paško prije formiranja Demokratske partije bili članovi Albanske partije rada. Prvi je tokom svog dvadesetpetogodišnjeg članstva bio na položaju partijskog sekretara na Fakultetu za medicinu Univerziteta u Tirani i inicijalno posrednik režima u smirivanju studenskih protesta. Takođe, kao kardiolog Beriša je nekoliko godina bio zadužen za zdravlje Envera Hodže. Ibid., p. 146. Među ostalim osnivačima Demokratske partije bili su i Aleksandar Meksi, Arben Imami, Genc Ruli, Eduart Selami i Azem Hajdari.

${ }^{42} \mathrm{U}$ razumijevanju iseljavanja može poslužiti i slučaj porodice Popa iz 1985. godine. Tada su članovi te porodice (dva brata i četiri sestre) pretvarajući da su italijanski turisti u razgovoru sa obezbjeđenjem ušli u dvorište italijanske ambasade. Na tlu ambasade, zaprijetili su samoubistvom ukoliko bi bili predati Sigurimi-ju, čiji su članovi odmah okružili ambasadu. Epilog slučaja bio je da su članovi porodice Popa živjeli u italijanskoj ambasadi sve do 1989. godine kada su dobili dozvolu za napuštanje NR Albanije. Vidjeti: Julie Vullnetari, Albanian Migration and Development: State of the Art Review, International Migration, Integration and Social Cohesion in Europe, Amsterdam, 2007, p. 31.

${ }^{43}$ Vidjeti: Agata Domachowska, "Albanian Migration as a Post-Totalitarian Legacy", Migration Studies - Review of Polish Diaspora, vol. 45, no. 2, 2019, p. 92. 
studenskim protestima koji su bjesnili na nasleđe Envera Hodže u Tirani, Drač tokom tih mjeseci postaje stecište naroda odlučnih ka emigraciji po svaku cijenu. Isprva su u februaru glasine o brodovima, koji su plovili iz Drača ka Italiji, okupile više hiljada ljudi, međutim luka u gradu bila je zatvorena što je praćeno intervencijom vojske, odnosno policije. ${ }^{44}$ Ipak, ovakvo stanje u dračkoj luci nije se moglo dugo održati. Već tokom sledećeg mjeseca preko 25.000 ljudi koristi sve što može poslužiti kao plovilo u cilju pristizanja ka lukama Brindizi, Bari, Ontranto i Monopoli na italijanskoj obali. Odgovor Nanove vlade na martovske događaje bio je da ista nema izbora, osim da dopusti odlazak naroda iz države. ${ }^{45}$ Takođe, iseljenici su u Italiji posmatrani kao političke izbjeglice, stoga im je dodijeljen isti status i docnije mogućnost ostanka u državi. Drugačija odluka donesena je u avgustu kada je približno 20.000 iseljenika, pretežno iz luke u Valoni (Vlorë), krenulo ka Italiji. Razlog repatrijacije albanskih iseljenika iz Barija pronađen je $\mathrm{u}$ održanju prvih demokratskih izbora u Albaniji marta 1991. godine i činjenica da se „avgustovski“ iseljenici nisu mogli tretirati kao političke izbjeglice. ${ }^{46}$

Pored iseljavanja u Italiju, kopnena granica sa Grčkom učinila je tu zemlju željenim odredištem za iseljenike iz Albanije. ${ }^{47} \mathrm{Za}$ razliku od „italijanskog slučaja“, iseljavanja u Grčku tokom 1991. godine nisu praćena adekvatnim statističkim procjenama. Međutim, podatak vrijedan značaja jeste da je tokom repatrijacije albanskih iseljenika (skoupa) u decembru 1991. godine, okvirno njih 100.000 vraćeno je u matičnu državu. ${ }^{48}$ Svakako da taj

${ }^{44}$ Premda su policija i vojska intervenisale, petnaest prenatrpanih brodova uspjelo je napustiti luku Drač, uključujući i brod Tirana, čija je posada bila primorana na plovidbu od strane iseljenika. Ibid., p. 93.

${ }^{45}$ Postojala su tumačenja da je Nanova vlada bila voljna da isprati iseljenike iz države, s obzirom na tadašnje predstojeće izbore i činjenicu da bi iseljenici dominantno glasali protiv Albanske partije rada.

${ }^{46}$ Plašeći se još jednog egzodusa, vlada Italije - ministar spoljnih poslova Đani de Mikelis (Gianni de Michelis) - uputila je donaciju Albaniji od 85 miliona dolara, što je bilo dovoljno da pokrije uvoz hrane u državu za naredna tri mjeseca. Takođe, dato je 50 miliona dolara za spasavanje fabričkih proizvodnih pogona. Zauzvrat, Bufijeva vlada je stavila luke u državi pod vojnu upravu i dogovorene su zajedničke vojne pomorske patrole. Pored ovog, sklopljen je još jedan sporazum sadržan u operaciji Pelikan, gdje je hiljadu italijanskih vojnika dostavljalo osnovne životne namirnice $u$ Albaniji. Smatra se da je ova operacija u velikoj mjeri doprinijela smanjenju gladi u Albaniji tokom 1991. godine. Fatos Tarifa, “Albania's Road from Communism: Political and Social Change, 1990-1993", op. cit., p. 153.

${ }^{47}$ Ovdje je odrednica drugačija, budući da su među iseljenicima u Grčkoj bili i pripadnici grčke nacionalnosti dominantno iz Đirokastre i Sarande, odnosno okoline tih gradova.

${ }^{48}$ Vidjeti: Julie Vullnetari, "Albanian Migration and Development: State of the Art 42 Review", op. cit., p. 33. 
broj ne obuhvata sve koji su prešli albansko-grčku granicu, što nas dovodi do zaključka da broj iseljenih iz prve u drugu državu je/može biti veći. Kada su u pitanju dalje emigracije iz Albanije, može se reći da je njihov intenzitet $\mathrm{u}$ narednom periodu donekle opao. Najprije, zbog predostrožnosti susjednih država prema ovom pitanju i činjenici da se sa promjenom vlasti u martu 1992. godine očekivao ekonomski napredak u Albaniji. Ipak, dolasku Demokratske partije na pozicije upravljanja državom prethodila je još jedna promjena vlasti, kada je nakon pada Nanove vlade ustanovljena vlada nacionalnog jedinstva predvođena Juli Bufijem (Ylli Bufi), postavljenog od strane predsjednika Alije. ${ }^{49}$

Bufijeva vlada nacionalnog jedinstva bila je proizvod široke koalicije, uključujući Republikansku, Socijaldemokratsku i Poljoprivrednu partiju, pored većih - Demokratske i Socijalističke. ${ }^{50}$ Posledica tog dogovora bilo je pristupanje države u Organizaciju za evropsku bezbjednost i saradnju (OEBS), ${ }^{51}$ zatim u MMF i Svjetsku banku. Važna je i posjeta državnog sekretara SAD, Džima Bejkera (Jim Baker), istog mjeseca, čime je nepobitno dat legitimitet kadrovskim promjenama u vladi. Ako uzmemo u obzir izolacionističku prošlost Albanije, pristupanje OEBS-u značajno je $u$ tome da bi ulazak u ovakvu organizaciju trebao ustanoviti univerzalni minimum ljudskih prava sa imperativom poštovanja, i $u$ tadašnjim posthladnoratovskim uslovima, prateći međunarodni pritisak ukoliko se suprotno djeluje. Drugi je da je učlanjenjem u ovaj mehanizam integracije Albanija mogla računati na preko potrebnu pomoć prevazilaženja poteškoća tranzicije (izgradnje države), gdje su tradicionalne vjerske, kulturne i druge razlike u državi svakako imale svoju ulogu. Premda se ekonomska situacija u državi dodatno pogoršala, ${ }^{52}$ vlada nacionalnog jedinstva uživala je kakvu-

${ }^{49}$ Odabir premijera od strane predsjednika bio je proizvod labavog dogovora između demokrata i socijalista, čime je ukinut ustav iz 1976. godine, odnosno donesen je Zakon o ustavnim promjenama predviđen da traje do donošenja novog ustava. Vidjeti: Fatos Tarifa: “Albania's Road from Communism: Political and Social Change, 1990-1993", op. cit., p. 152.

${ }^{50}$ Ime Albanska partija rada promijenjeno je na partijskom kongresu u maju 1991. godine u Socijalističku partiju.

${ }^{51}$ Za napomenuti je da je preoblikovanje Sigurimi-ja u Nacionalnu obavještajnu službu (Shërbimi Informativ Kombëtar - SHIK) prethodilo pristupanju u OEBS.

${ }^{52}$ Takvo dodatno pogoršanje najbolje se može opisati time da bi nedostatak osnovnih životnih namirnica sigurno prevagnuo, budući da je industrijska proizvodnja opala za $50 \%$, cijene su porasle za $500 \%$ dok su plate ostale fiksirane, poljoprivredna aktivnost je pala za $75 \%$ kao posledica rasprava oko podijele bivših kolektivnih farmi u privatne posjede. Veliku ulogu u sprečavanju gladi slanjem humanitarne pomoći imale su Grčka, Italija i Evropska zajednica.

Vidjeti: Fatos Tarifa: “Albania's Road from Communism: Political and Social Change, 1990-1993", op. cit., pp. 155-156. 
takvu blagonaklonost naroda, najviše zbog činjenice da određeni članovi vlade nisu bili dio komunističkog sistema. U prilog tome treba dodati međunarodnu raznovrsnu podršku koju je Albanija dobila tokom trajanja ove vlade. Ipak, ista je svoje postojanje okončala u decembru 1991. godine, kada Sali Beriša donosi odluku o izlasku Demokratske partije iz zajedničke vlade prouzrokujući time nove izbore u državi. Uporište za ovakvu odluku Beriše (i drugih članova Partije) nedvosmisleno je bilo u tadašnjoj političkoj situaciji u Albaniji, odnosno sigurnog izostanka izborne utakmice, s obzirom na količinu podrške koju je Socijalistička partija tada uživala.

\section{Albanske krivine demokratskog neiskustva 1992-1996}

Radi razumijevanja (pred)izbornog procesa u Albaniji, marta 1992. godine, potrebno je imati na umu činjenicu da je opoziciona Demokratska partija (DP) primjetan dio svog izbornog potencijala crpila iz antikomunističkih narativa i osjećanja u albanskom društvu. Direktna posledica takvog stanja jeste osjetno uvećanje broja članova i raznovrsnih političkih skupina unutar DP. Sa druge strane, Socijalistička partija, nakon višedecenijske komunističke uprave u državi i neuspjeha Nanove vlade, jednostavno nije imala snage da sebe predstavi kao zapaženog takmaca izborne utakmice. Eventualna pobjeda socijalista možda i ne bi bio poželjan ishod po albansko društvo, uzevši u obzir previranja između 1990. i 1992. godine. Takođe, Demokratska partija je pronašla dodatan izvor podrške u međunarodnoj zajednici. ${ }^{53} \mathrm{Uz}$ obećanja o obilnoj humanitarnoj inostranoj pomoći, ${ }^{54}$ predizborna kampanja DP zasnivala se na demokratizaciji Albanije, sveobuhvatnim ekonomskim reformama i usmjeravanju države prema zapadu. Ovdje je zanimljivo navesti da su ekonomske reforme, koje su predstavljale jedan od stubova predizborne kampanje DP, a koje su podrazumijevale primjenu „,̌̌ok terapije“" bile u očiglednoj suprotnosti sa rezultatima istraživanja Informativne agencije SAD iz 1991. godine. Prema njima, čak 45\% Albanaca izrazilo je stav da država treba da preuzme veću odgovornost za pružanje usluga svim građanima. ${ }^{55}$ Izborna pobjeda DP bila je prognozirana, međutim $62 \%$ osvojenih glasova predstavljalo je najviše potvrdu antikomunističkog sentimenta u Albaniji, kapitalizovanog od

${ }^{53}$ Predizborni slogan DP bio je „Mi upravljamo, svijet nam pomaže“ (Ne qeverisim, bota na ndihmon).

${ }^{54}$ U prilog ovome je i izjava Gramoza Paška o „,blanko čeku“ humanitarne pomoći od Stejt departmenta (State Departmant) SAD u slučaju opozicione pobjede. Fatos Tarifa: "Albania's Road from Communism: Political and Social Change, 1990-1993", op. cit., p. 156.

${ }^{55}$ Vidjeti: Blendi Kajsiu, "Down with Politics! The Crisis of Representation in Post-

44 Communist Albania", op. cit., p. 237. 
strane Sali Beriše i ostalih prvaka DP. Ipak takav sentiment, koji je bio proizvod želje za promjenom vlasti i ekonomskim boljitkom, ujedinjavao je mnogobrojne grupe unutar i van DP. Smjenom vlasti, najsnažnije vezivno tkivo dotadašnje opozicije je nestalo. Time se uspješnost predsjednika Beriše i izabranog premijera Aleksandra Meksija mogla mjeriti samo u ispunjavanju predizbornih obećanja i neponavljanju odlika ponašanja prethodne vlasti, od kojih je drugo posjedovalo teret prošlosti.

Preuzimanjem vlasti privremeno je umanjen intenzitet političke nestabilnosti, što je omogućilo pokretanje ekonomskih reformi. Prethodno njihovom iniciranju, spoljni dug iznosio je $30 \%$ bruto domaćeg proizvoda (BDP), devizne rezerve bile su istrošene, deficit u budžetu imao je tendenciju rasta sa $44 \%$ na $50 \%$ do kraja 1991. godine. Kao rezultat finansiranja tog deficita, količina novca u opticaju se udvostručila i predstavljala je čak $69 \%$ BDP-a. Sa tim, inflacija je iznosila preko $200 \% .{ }^{56}$ Reforme su u javnosti predstavljane kao posebno neophodne za demokratiju i otklon od bivšeg komunističkog sistema, iako zapažen dio društva isprva nije bio u potpunosti upoznat sa sadržinom tih reformi. S obzirom na inostranu predizbornu ulogu za očekivati je bilo da ekonomsko preoblikovanje Albanije bude potpomognuto pomoću MMF-a. Prvi dio reformi u periodu od godinu dana (1992-1993), ${ }^{57}$ sastojao se u stabilizaciji makroekonomskih prilika, usredsređen ka smanjivanju inflacije putem posredne i neposredne kontrole monetarnih instrumenata i sprovođenja striktne fiskalne kontrole. ${ }^{58}$ Primjena ovog modela zahtijevala je dobrano smanjenje zaposlenih $u$ javnom sektoru i podsticanje privatnog preduzetništva. Rezultati stabilizacije prvenstveno su se ogledali u snižavanju stepena inflacije koja je već krajem 1993. godine iznosila 31\% (16\% 1994, a 5\% 1995. godine). ${ }^{59}$ Zatim, opadanjem udjela budžetskog deficita BDP-a, najprije kroz izostanak subvencija državnim preduzećima i povećanja količine novca prikupljenog kroz novi sistem naplate poreza sve većem broju privatnih preduzeća. ${ }^{60}$ Treća reperkusija jeste redukovanje zaposlenih u javnom sektoru - 1992. godine 615.000 naspram 889.000 koliko je bio 1989. godine.${ }^{61}$ Premda je ovo

${ }^{56}$ Marta Muço, Economic Transition in Albania: Political Constraints and Mentality Barriers, 1997, Internet, https://www.nato.int/acad/fellow/95-97/muco.pdf, 04/12/2020, p. 20.

${ }^{57} \mathrm{U}$ okviru aranžmana sa MMF-om, Albanija je za navedeni period dobila kredit od 29 miliona dolara. Ibid., p. 21.

${ }^{58}$ Ibid., p. 21.

${ }^{59}$ Ibid., p. 22.

${ }^{60}$ Primjetna je razlika između broja privatnih preduzeća u Tirani u martu 1991. i decembru 1992. godine - 398 naspram 8.321. Dirk J. Bezemer, "Post-socialist financial fragility: the case of Albania." Cambridge Journal of Economics, vol. 25. no. 1, 2001, p. 3.

${ }^{61}$ Zaposlenih u javnom sektoru 1995. godine bilo je svega 275 hiljada (u odnosu na 1989. godinu). Blendi Kajsiu, “Down with Politics! The Crisis of Representation in Post-Communist Albania", op.cit., p. 237. 
poslednje uticalo na porast nezaposlenosti, sprovedena stabilizacija dopustila je ubrzani prelazak na druge dvije faze u (ekonomskoj) tranziciji Albanije - liberalizaciju i privatizaciju, takođe sprovođene kroz saradnju sa MMF-om od 1993. do 1996. godine.${ }^{62}$ Rapidno povlačenje države iz privrede iziskivalo je napuštanje kontrole cijena u korist tržišta, zatim uspostavu slobode spoljne trgovine i time prihvatanje prodora inostranih proizvoda na domaćem tržištu.$^{63}$ Liberalizacija (spoljne) trgovine praćena je uvođenjem fluktuirajućeg kursa domaće valute (lek), koji je učinjen interno konvertibilnim, te je njegova kupovna moć mijenjana shodno zahtjevima sada bitno drugačijeg tržišta. Kada je u pitanju privatizacija, ona je $u$ navedenom periodu činjena zapaženom brzinom i pretežno vezana za mala preduzeća uslužne - potrošačke kategorije, gdje su postojale poteškoće zbog nedostatka pravnog okvira. Pored ovog, privatizacija je najviše odmakla u domenu obradive površne. ${ }^{64}$ Zakon iz 1991 . godine, prema kojem su činioci zadruga dobili zemlju prethodno zadružnog vlasništva učinivši ih tako nezavisnim poljoprivrednicima, nije povučen već je na taj zakon donesen još jedan iz 1993. godine. Taj kasniji zakon odnosio se na restituciju zemlje nacionalizovane 1946. godine, čime je pružen djelimičan povraćaj imovine vlasnicima zemlje prije komunističke reforme vlasničke strukture. Činjenica je da se kao posledica sukcesivnog sprovođenja ovih faza ekonomska situacija $u$ državi djelimično popravila, te da je Albanija nerijetko predstavljana kao tranzicioni primjer među postkomunističkim državama. ${ }^{65}$ Međutim, realna i objektivna analiza treba da uključuje: polaznu osnovu ekonomskog razvoja, tadašnje prioritete međunarodne zajednice, izrazite društvene i političke implikacije preuzetog pristupa ekonomskog preoblikovanja zajedno sa još uvijek (pre)slabim institucijama i povratnog uticaja albanskih iseljenika sa tržišnim nedostacima u državi. Sjedinjavanje prethodnog uticaće na ponovnu pojavu nesigurnosti među albanskim narodom od sredine 1996, i naročito početkom 1997. godine.

${ }^{62} \mathrm{U}$ okviru druge faze - Proširene olakšice za strukturno prilagođavanje (Enhanced structural adjustment facility), Albanija je pozajmila 60 miliona dolara od MMF-a sa kamatnom stopom od 5\% i rokom otplate od 10 godina. Marta Muço, "Economic Transition in Albania: Political Constraints and Mentality Barriers", op. cit., p. 21.

${ }^{63}$ Zanimljiva je drastična promjena izvoznih partnera Albanije između 1989. i 1995. godine. Prve, čak 46,3\% albanskog izvoza išlo je ka državama iz Savjeta za uzajamnu ekonomsku pomoć, dok je taj procenat 1995. godine iznosio nešto više od $10 \%$. Tu prazninu popunio je izvoz ka EU i EFTA državama članicama koji je 1995. godine bio preko 80\% - Italija: 51,53\% izvoz, 37,88 uvoz, Grčka: 9,93\% izvoz, 26,78\% uvoz. Ibid., pp. 25, 83.

${ }^{64}$ Vidjeti više: Sherif Lusho \& Dhimitër Papa, Land Fragmentation and Consolidation in Albania, 1998, Internet, https://minds.wisconsin.edu/bitstream/handle/1793/219 65/50_wp25.pdf?sequence=1\&isAllowed=y , 23/11/2020.

$46{ }^{65}$ Albanija je nerijetko predstavljana kao „najposlušniji student” MMF-a. 
Ekonomsko preoblikovanje bila je posledica zauzimanja bitno drugačijeg spoljnopolitičkog pristupa u odnosu na period između 1990. i 1992. godine. Može se reći da su vlade, pre 1992. godine, međunarodnu saradnju i integraciju u međuvladine organizacije opštijeg karaktera posmatrale kao sredstvo za stabilizaciju prilika u državi i pružanje legitimiteta tadašnjim državnim upravama. Sa druge strane, predizborni interval najavio je razvijanje i usmjeravanje međunarodne saradnje Albanije, te pristupanje evroatlantskim mehanizmima integracije kao vanjskopolitičke prioritete Albanije i (posebno) predsjednika Beriše.

Dakle, ako je spoljnopolitička aktivnost jedne države podijeljena između izbora, želja i prirodne usmjerenosti, onda se te aktivnosti Albanije u prvom domenu primarno vezuju za SAD i NATO, većinom komplementarne i Saveznu Republiku (SR) Njemačku. Kada su u pitanju SAD, odnosi su bili političkog i vojnog karaktera. Bliske političke relacije sa SAD bile su od osobite važnosti za Albaniju, koja je pripadništvo američkom "kišobranu“ posmatrala stubom sigurnosti države u izazovima Balkana. ${ }^{66} \mathrm{Za}$ SAD i NATO takvi odnosi bili su podstaknuti geostrateškim položajem Albanije, naročito u odnosu na disoluciju bivše Jugoslavije i snaženja prisustva SAD i NATO na jugoistoku Evrope po završetku Hladnog rata. ${ }^{67}$ Sledstveno tome, Albanija već 1992. godine izražava želju za NATO članstvom, da bi iste pristupila Sjevernoatlantskom savjetu za saradnju, odnosno Partnerstvu za mir dvije godine kasnije. Takođe, ne treba zanemariti i suštinske međunarodne promjene i Berišino barem normativno antikomunističko raspoloženje. Ipak, geostratešku i geopolitičku važnost Albanije, predsjednik Beriša je nerijetko koristio kao zaleđe za obračune sa političkim protivnicima, koji su okarakterisani kao zabrinjavajući porast autoritarnih tendencija predsjednika i kasnije uticali su na pojavu nemale dvosmislenosti u odnosima SAD prema Albaniji (Beriši). Međutim, oni takav karakter počinju gubiti sa kontroverzama na parlamentarnim i lokalnim izborima 1996. godine. Što se tiče odnosa sa SR Njemačkom, oni su bili određeni obostranom političkom potrebom. Za Berlin, potreba se sastojala $u$

${ }^{66}$ Remzi Lani \& Fabian Schmidt, "Albanian foreign policy between geography and history", The International Spectator: Italian Journal of International Affairs, vol. 33, no. 2, 1998, p. 91.

${ }^{67} \mathrm{U}$ prilog ovome, pored pristupanja Albanije u Partnerstvo za mir, jeste činjenica da su u vršenju izviđačkih misija u operacijama "Sigurni raj“ (Save Heaven) i „Spriječiti let" (Deny Flight), američke letjelice tokom iste godine kao bazu koristile vojni aerodrom u Đaderu na sjeveru Albanije. Adem Copani \& John Sray, Partnership for Peace and New Dimensions of Albania's Security Posture, 1996, Internet, https:// community.apan.org/wg/tradoc-g2/fmso/m/fmso-monographs/244584, 05/12/2020, pp. 5-6. Takođe, prethodno raspoređivanju u BiH, snage IFOR su bile stacionirane u Albaniji. Ryan Hendrickson, "Albania and NATO: Regional Security and Selective Intervention”, Security Dialogue, vol. 30. no. 1, 1999, p. 111. 
političkim vezama sa vladom u Tirani i predsjednikom Berišom, koje se odnose na dugoročne strategije SR Njemačke posredstvom balkanskog poluostrva. Za Albaniju jezgro veće potrebe bila je rastuća ekonomska i politička moć SR Njemačke nakon ujedinjenja. ${ }^{68}$ Premda su se izborni događaji tokom 1996. godine istovjetno odrazili kao u slučaju relacija sa SAD, može se reći da su nastojanja SAD i SR Njemačke shodno Albaniji ostala nepromijenjena i nakon smjene vlasti u državi 1997. godine. Pored prethodnih država, za napomenuti jeste „izlet“ Albanije prema Organizaciji islamske saradnje. Iako se očekivala (obećavala) velika finansijska pomoć, ta kratkovremena strategija okončana nakon mandata Beriše, najviše se reflektovala $\mathrm{u}$ jačanju islama $\mathrm{u}$ državi. Za Albaniju, poveznica između izbora i prirodne usmjerenosti u spoljnoj politici države je Turska. Svakako da se drugo odnosi na islam kao posledicu istorijskih prilika iz kojih proizilaze temeljne kulturne spone između dva naroda. Na osnovu toga ističe se izbor vojnog partnerstva Ankare i Tirane, što će zajedno sa kulturnom srodnošću biti konstanta u narednom periodu.

Ako poveznicu između izbora i usmjerenosti čini Turska, za Albaniju drugo polje nesumnjivo sačinjavanju Italija i Grčka. Ipak, ovdje treba napraviti razliku u angažovanosti tih država prema Albaniji. Za Italiju, političko djelovanje prema Albaniji gotovo je $u$ potpunosti bilo humanitarnog karaktera, budući da su brojne krize u drugoj pretpostavile odgovornosti Rima da sanira štetne posledice kriza. Iako je Italija u oblasti ekonomije bila dominantna na albanskom tržištu, italijanski izvoz u ukupnom njegovom udjelu nije pratio takvu zastupljenost. ${ }^{69} \mathrm{Za}$ Grčku, pored humanitarnih razloga, postojanje grčke manjine $u$ Albaniji iziskivalo je političko djelovanje Atine prema Tirani, posebno zbog poteškoća koje su politički predstavnici te manjine iskusili tokom mandata Beriše. ${ }^{70}$ Značajnu odrednicu albansko-grčkih odnosa imalo je ponovno organizovanje Pravoslavne crkve u Albaniji, crkve nakon više decenija komunizma i

${ }^{68}$ Za napomenuti je narativ koji je Njemačka uživala među albanskim narodom, naravno kao najveći saveznik pored SAD u rešavanju statusa Kosova. Vidjeti: Remzi Lani \& Fabian Schmidt, "Albanian foreign policy between geography and history", op. cit., p. 94.

${ }^{69} \mathrm{U}$ poslednjoj punoj godini mandata Beriše, izvoz Italije u Albaniju iznosio je 450 miliona dolara ili 0,18\% ukupnog izvoza Italije. 1996, Internet, https://wits. worldbank.org/CountryProfile/en/Country/ITA/Year/1996/TradeFlow/Export /Partner/by-country , 05/12/2020.

${ }^{70} \mathrm{U}$ avgustu 1994. godine, pet lidera političke partije Omonia uhapšeni su zbog navodnog špijuniranja albanskih vojnih baza i separatističkih težnji u cilju promovisanja grčkih teritorijalnih interesa na jugu Albanije. Navođeno je povezivanje sa Grčkom pravoslavnom crkvom i tajnom službom radi podizanja ustanka protiv Albanije. Remzi Lani, Fabian Schmidt,"Albanian foreign policy between geography and history", op. cit., p. 88 . 
dobrodošle uloge grčkih sveštenika u tom procesu. ${ }^{71} \mathrm{U}$ ekonomiji, grčka poljoprivreda u velikoj mjeri zavisila je od albanskih sezonskih radnika, dok je razlika između zastupljenosti Grčke na albanskom tržištu, prema grčkom izvozu u Albaniju, svakako bila manja nego u slučaju Italije. ${ }^{72} \mathrm{U}$ albanskoj javnosti postojala je „Rim-Atina dilema“, tj. pitanje albanske orijentacije. Ipak, nužnost grčkih nacionalnih interesa - zaštita svoje manjine u Albaniji uticala je da javnost i tadašnja vlast bude relativno naklonjena Rimu.

Kada su u pitanju unutrašnja političko-društvena kretanja u Albaniji tokom mandata Beriše, neophodno je zauzeti širi analitički pristup. Na osnovu toga, činjenica je da je albanski narod karakterističan po velikom broju unutrašnjih međusobnih razlika, te da su one tokom istorije zaslužne za razvoj partikularne svijesti među tim narodom. Takvo stanje omogućilo je podastiranje autoriteta centralnih vlasti u Albaniji tokom prve polovine XX vijeka. Međutim, nakon narodnooslobodilačke borbe i revolucije, osjetne različitosti i partikularna narodna svijest predstavljale su ozbiljnu smetnju za stvaranje snažne centralne vlasti i dubinski integrisane albanske nacije. Stoga su mnogobrojne osobenosti albanskog naroda, najblaže rečeno, bile obeshrabrivane, budući da su doživljavane kao prijetnja pomenutim prioritetima nove vlasti. Ipak, može se reći da su blagu prednost u ispunjavanju te zamisli imale albanske osobenosti sa juga zemlje..$^{73}$ Takva nastojanja rezultirala su ekonomskim i socijalnim napretkom (ponajviše u pružanju javnih usluga), zatim uklanjanju protivljenja jakoj centralnoj vladi i znatnom smanjenju albanske unutrašnje raznolikosti. Ti naumi proizveli su približno sveobuhvatnu kontrolu svakodnevnih tokova života albanskog društva. Pa ako uzmemo u obzir tekovine ovakvog sistema upravljanja, sigurno je da će na njegovo urušavanje jedina osnova reakcije naroda biti krajnost. Takođe, sjedinjavanje preuzimanja vlasti jedne načelno demokratske partije, međutim sa predvodnicima kojima je manjkalo demokratskog iskustva, i hitro sprovedene ekonomske liberalizacije, uticalo je

${ }^{71}$ Ipak, nije sve išlo glatko. Negativne posledice bile su sadržane u tome što mitropolit

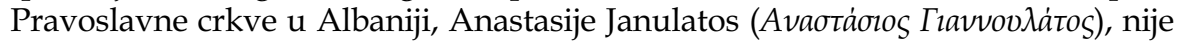
posjedovao albansko državljanstvo, a prema kontroverznom ustavnom predlogu iz 1994. godine strano lice nije moglo biti na čelu jedne vjerske zajednice. Premda ustavni predlog nije usvojen, pomenuta odrednica naštetila je odnosima između Pravoslavne crkve i vlasti u Albaniji, iako je uloga grčkih sveštenika i samog mitropolita u obnovni prve bila istorijska. Vidjeti: Ibid., p. 88.

${ }^{72} \mathrm{Za}$ istu godinu, grčki izvoz u Albaniju je bio nešto manji (322 miliona), međutim značajno većeg udjela u ukupnom izvozu Grčke - 2,72\%. 1996, Internet, https://wits.worldbank.org/CountryProfile/en/Country/GRC/Year/1996/Trade Flow/Export/Partner/by-country , 12/12/2020.

${ }^{73} \mathrm{~S}$ obzirom na pomenute prioritete komunističke vlasti u Albaniji u ovakvom razumijevanju na umu treba imati mentalitet koji je (bio) rasprostranjen na sjeveru države, a koji (je) često prikaz(ivao)uje karakteristike prkosa i nepokoravanja spoljnim subjektima. 
ne samo da se albanske raznolikosti u potpunosti povrate, već i da njihov efekat bude mnogo snažniji.

Pored političkih tekovina Berišinog predsjedničkog mandata, veoma je važno istovremeno se koncentrisati ka društvenim reperkusijama njegove uprave. Jedinstvo koje je bilo posledica nastojanja za smjenom komunističke vlasti među političkim predstavnicima i narodom, vrlo brzo se raspršilo nakon iste. U paru sa rastom autoritarizma predsjednika jesu višestruke (negativne) posledice (pre)brzog povlačenja države iz mnogobrojnih sfera društvenog života. Albanci su u izuzetno kratkom razdoblju prešli iz sveprožimajućih ograničenja $u$ ustrojstvo obrnuto proporcionalno prethodnom. Iako je takav "prelaz" obezbijedio spoljnopolitički legitimitet za Berišinu vlast, na unutrašnjem planu imao je zabrinjavajuće posledice. Nakon višedecenijskog komunizma i zastrašujućih poteškoća po albanski narod između 1990. i 1992. godine, dati stepen sloboda nije bio praćen adekvatnim strategijama vlasti na društvene izazove ekonomskog preoblikovanja. Zapravo, takve slobode bilo je veoma teško razlikovati od ekonomskog i društvenog bezvlašća u državi. ${ }^{74}$ Time je prouzrokovana dalja polarizacija i međusobno udaljavanje unutar albanskog društva. Takve slobode bile su najvidljivije u unutrašnjoj migraciji (najčešće sa manje razvijenog sjevera ka jugu), ekonomskoj reformi društva koje je od kakvetakve samodovoljnosti, sada bilo osjetno potrošački nastrojeno, zatim osjećaju nesigurnosti proisteklog iz drastičnog smanjenja javnog sektora i nestanka državnih subvencija, odnosno pomoći skladno uputstvima MMF-a. ${ }^{75}$

$S$ obzirom na takve posledice i nemogućnosti nove vlasti u pronalasku metoda društvenog i održivog ekonomskog razvoja, kao strategiju snaženja sopstvenih stubova podrške korišćen je antikomunistički narativ. Budući da su obećanja o ubrzanom približavanju Evropi odigrala svoju izbornu ulogu, „razumljivo“ je ovakvo okretanje ka antikomunističkom diskursu. Kako su svakodnevne ekonomske glavobolje naroda ostajale neriješene, i time potencijalno ugrožavale rezultate parlamentarnih izbora, prisutnost takvog obrasca sve više se povećavala. Stvaranje antikomunističkog konstrukta temeljilo se na predstavljanju opozicione Socijalističke partije kao partije željne vlasti bez obzira na cijenu, partije usmjerene ka ponovnom uspostavljanju komunističke diktature, pri čemu su isticana stravična događanja između 1990. i 1992. godine. ${ }^{76}$ Može se reći da su rezultati lokalnih izbora jula 1992. godine za Demokratku partiju bili otrežnjujući. Iako je pomenuta stranka bila prva po broju osvojenih glasova, znatno

${ }^{74}$ Blendi Kajsiu, "Down with Politics! The Crisis of Representation in Post-Communist Albania", op. cit., p. 237.

${ }^{75}$ Vidjeti: Bernd J. Fischer, “Albania since 1989: The Hoxhaist Legacy”, op. cit., p. 482.

${ }^{76}$ Isto tako, društvene i ekonomske neprilike koje je stanovništvo u Albaniji doživljavalo nisu bile proizvod pogrešnih reformskih pristupa, već neophodna

50 cijena postkomunističke tranzicije, kako je navođeno iz Demokratske partije. Vidjeti: 
manja razlika u odnosu na Socijalističku partiju, odrazila se na pojačanje antikomunističkog narativa. Time su nedugo nakon lokalnih izbora "socijalni komunisti“", kako su nazivani iz vladajuće partije, postali predmet višestrukih optužbi zloupotrebe državnih položaja. Već 1993. godine, na osnovu navodnog tereta korupcije, uhapšeni su i osuđeni na devet, odnosno dvanaest godina, bivši predsjednik Alija i premijer Nano. ${ }^{77}$ Po zatvaranju socijalističkih prvaka procijenjen je pogodan trenutak za novim ustavom Albanije, koji bi drastično osnažio predsjednikovu poziciju. Premda su demokrate posjedovale komotnu većinu u parlamentu, za promjenu ustava nisu imale dovoljnu podršku, stoga je odabrano da predlog ustavnih reformi bude odlučen referendumom. Ovdje je važno naglasiti da uprkos ograničenom demokratskom iskustvu, predlog ustavnih reformi na referendumu je odbačen, prevashodno jer su one predviđale suvišna izvršna ovlašćenja predsjednika republike. ${ }^{78}$ Takođe, ovakav odgovor pokazuje da pedeset godina jednopartizma ne dovodi nužno do nestanka demokratskih principa u jednom društvu.

Rezultati referenduma uticali su na ponovni porast antikomunističke kampanje. Približavanjem parlamentarnih izbora 1996. godine postojalo je očigledno nastojanje da izborni ishodi budu neupitni. Uporedo sa konstantnom brigom o podobnosti kadrova $u$ državnim $i$ drugim strukturama, u julu 1995. godine novine Tirana Demokratike objavile su takozvane liste za odstrel. Liste, koje su navodno bile sačinjene od strane bivše komunističke vlasti, predviđale su likvidaciju brojnih protivnika bivšeg komunističkog sistema bez suđenja. ${ }^{79}$ Zapravo, pomenute liste vodile su ka, do tada, nezabilježenom stepenu antikomunističkog narativa koji je izjednačavao komunizam sa genocidom. U skladu sa članovima 67 i 74 Krivičnog zakonika Albanije, u septembru iste godine donesen je Zakon o genocidu s ciljem ubrzanja krivičnog gonjenja zbog kršenja osnovnih ljudskih prava i sloboda od bivših komunističkih vlada NR Albanije. ${ }^{80}$

Blendi Kajsiu, "Down with Politics! The Crisis of Representation in Post-Communist Albania”, op. cit., p. 237.

${ }^{77}$ Hapšenja i zatvaranja opozicionih predvodnika, praćena su restriktivnim zakonom o štampi, koji je ustanovio visoke poreze i nametanje teških novčanih kazni i kazni zatvora. Takve odredbe su zastrašili i samocenzurisali štampu, što je podstaklo mnogobrojne upitnosti o kvalitetu štampanih medija i time smanjenju čitalačke publike. Bernd J. Fischer, "Albania since 1989: The Hoxhaist Legacy", op. cit., p. 484.

${ }^{78}$ Clarissa de Waal, "From Laissez-Faire to Anarchy in Post-Communist Albania", The Cambridge Journal of Anthropology, vol, 20, no. 3, 1998, p. 35.

${ }^{79}$ Blendi Kajsiu, "Down with Politics! The Crisis of Representation in Post-Communist Albania", op. cit., p. 238.

${ }^{80}$ Puno ime zakona glasilo je: Zakon o genocidu i zločinima protiv čovječnosti počinjenim u Albaniji tokom komunističke vladavine iz političkih, ideoloških i religioznih motiva. 
Takođe, odrednice pomenutog zakona su do decembra 2001. godine onemogućile licima koja su suštinski bila dio vrha vlasti do marta 1991. godine kandidovanje za položaje lokalnih i centralnih organa vlasti. ${ }^{81}$ Zanimljivo da je sam Beriša bio dio prethodnog sistema u svojstvu partijskog sekretara i ličnog doktora Envera Hodže, stoga se vodilo računa o podesnosti zabrane. Dalje osiguranje izborne pobijede ogledalo se kroz "Zakon o dosijeima", prema kojem je uspostavljena istovjetna zabrana za svakog ko je (prema odluci posebno uspostavljenog komiteta) sarađivao sa bivšom službom Sigurimi ${ }^{82}$ Što se tiče izbornih rezultata, ${ }^{83}$ oni nisu donijeli nikakve promjene u odnosu na kampanju koja im je prethodila. Međutim, spoljnopolitičko zaleđe koje je Beriša uživao počelo je pokazivati ozbiljne znake slabosti. Sa međunarodne instance upućivani su višestruki zahtevi za ponavljanje izbora, dok su iz država(e) koje su bile primarni podržavaoci Berišine uprave stizale nedvosmislene osude izbornog ishoda. Te osude će rezultirati u eroziji i naposletku nestanku međunarodne potpore za tadašnjeg predsjednika Albanije.

Iskorakom u neoliberalizam nova vlast je pred sobom postavila veliki izazov, prvenstveno usled činjenice da neoliberalizam iako ne vuče društvo

${ }^{81}$ Zabrana se odnosila na: bivše članove Političkog odbora i Centralnog komiteta Albanske partije rada, zatim ministrima i zamjenicima Narodne skupštine, članovima Predsjedničkog vijeća, predsjedniku Vrhovnog suda, javnom tužiocu, prvim sekretarima distrikta, zaposlenima u Državnom sekretarijatu, saradnicima istog i svim onima koji su kao svjedoci naštetili optuženicima u političkim procesima, sa izuzetkom ako su djelovali protivno zvaničnom narativu i javno se udaljili od istog. Law Nr. 8001 on Genocide and Crimes against Humanity Committed in Albania during Communist Rule for Political, Ideological and Religious Motives, 2018, Internet, http:/ / www.derechos.org/intlaw/doc/alb2.html , 24/12/2020.

U maju 1996. godine na smrtne kazne osuđeni su: Aranit Cela (bivši predsjednik Vrhovnog suda), Rapi Mino (Rrapi Mino) (javni tužilac), Ziliftar Ramizi (Zylyftar Ramiyz) (zamjenik ministra unutrašnjih poslova i direktor Sigurimi-ja), Hadži Leši (Haxhi Lleshi) (predsjednik republike 1953-1982) i Manuš Muftiu (Manush Myftiu) (zamjenik premijera). Narednog mjeseca smrtne kazne su opozvane, Cela i Mino su osuđeni na 25 godina zatvora, dok su drugi pomenuti dobili doživotne kazne zatvora. Robbert Bideleux \& Ian Jeffries, The Balkans, a post-Communist history, Routledge, New York, 2007, p. 47.

${ }^{82}$ Zakon je omogućavao otvaranje arhiva Sigurimi-ja, pomoću kojih su kandidati za parlament, lokalnu i centralnu vlast provjeravani od strane državnog komiteta. Ibid., pp. $46-47$.

${ }^{83}$ Demokratska partija - 914,218 - 55,5\% glasova ili čak 122 poslaničkih mjesta, naspram Socijalističke partije - 335,402 - 20,4\% glasova, odnosno samo 10 poslaničkih mjesta, Dio socijalista je i bojkotovao izbore.

Vidjeti: IRI Observation Report on the Albanian Parliamentary Elections of May 26, 1996, 1996, Internet, https://www.iri.org/sites/default/files/Albania's\%201996\%20 Parliamentary\%20Elections.pdf, 16/01/2021. p. 33. 
dublje ka podjelama, ne predstavlja idealno ideološko podneblje odakle se može graditi objedinjujući društveni diskurs ${ }^{84}$ Samim time, poteškoće pronalaženja vezivnog društvenog tkiva postale su očigledne. U veoma suženom manevarskom prostoru rešenje koje je povećavalo šanse za dalji nastavak uprave načelno demokratskih vlasti, a koje je dugoročno štetilo preostalim naznakama jedinstva, bilo je podsticanje antikomunističkog sentimenta. U nemogućnosti pronalaska pozitivnog obrasca kohezije, prve postsocijalističke vlasti posezale su za onim negativnim. Takav izbor i naprasni obračuni sa predstavnicima bivšeg sistema vlasti veoma se negativno odrazio na albansko društvo, posmatrajući sa duže vremenske distance. Time je uprava Demokratske partije u podrobnoj mjeri podsjećala na prethodne garniture vlasti, najprije kada je riječ o načinu suočavanja sa svojim političkim protivnicima nakon Drugog svjetskog rata. Da li su takvi društveni narativi i metode političkog nadmetanja nužne u svakom procesu političke tranzicije u postsocijalističkim državama? Kao odgovor mogu poslužiti rezultati referenduma iz 1994. godine, gdje u razmatranje treba uzeti višedecenijski komunizam u državi.

\section{Dollari, dhrahmi, lira $i$ (ponovni) kolaps $u$ Albaniji}

Prije pobune ili građanskog rata u Albaniji (u zavisnosti od ugla posmatranja), od ključnog značaja za ovo istraživanje jeste raščlanjivanje događaja i utvrđivanje činjenica koje su prouzrokovale nesretna dešavanja u Albaniji tokom 1997. godine. Nezaobilaznu ulogu u tome imaju piramidalne šeme ${ }^{85}$ koje su (samo) godinu dana ranije predstavljale središnji dio (gotovo) svih tokova života u Albaniji. Za njihovo temeljno razumijevanje neophodno je osvrnuti se na efekte procesa iseljavanja iz Albanije, započetog

${ }^{84}$ Blendi Kajsiu, "Down with Politics! The Crisis of Representation in Post-Communist Albania", op. cit., p. 237.

${ }^{85}$ Piramidalne šeme u Albaniji vode svoje porijeklo od Ponzijevih prevara. One se sastoje $\mathrm{u}$ "preduzetniku“ kojem je potreban novac - gotovina pod izgovorom o „profitabilnoj investiciji“. Taj preduzetnik na pozajmljeni novac nudi (pre)velike kamatne stope privlačeći tako „investitore“. Isprva, on uspijeva u izmirivanju tih kamatnih stopa, budući da je tu priliku o profitabilnoj investiciji predočio i mnogobrojnim drugim investitorima. Takođe, od značaja je da investitori u početku ne preuzmu svoje depozite, već da ih ostave kod preduzetnika čime se stiče kapitalna osnova za izmirivanje drugih kamatnih stopa i samim time se piramidalne šeme zahuktavaju. Moguće je da preduzetnik u početku vrati glavnicu i isplati kamatne stope, čime zadobija povjerenje i podstiče omasovljenje. Ipak, svaka piramidalna šema se završava u neuspjehu budući da pozajmljeni novac ne stvara novi novac, već služi za isplatu ranijih depozita i kamatnih stopa. Onog trenutka kada dođe do zasićenja - nestanka novih depozita tada se u teoriji urušavaju piramidalne šeme. Ipak, postojali su drugačiji slučajevi - bjekstvo preduzetnika sa pozajmljenim novcem. 
1990. godine. ${ }^{86} \mathrm{~S}$ obzirom na raznovrsne ekonomske nesigurnosti za domaćinstva u Albaniiji, jedan od njihovih glavnih izvora prihoda bile su inostrane doznake. Koliki su značaj doznake imale predstavlja činjenica da je emigracija ubrzo postala važna vrsta (kolektivnih) investicija. ${ }^{87}$ Stotine hiljada Albanca bilo je angažovano u kretanju ljudi i novca, negujući time obrasce i mreže emigracije kao alternativnog , investicionog repertoara.“ ${ }^{48}$ Premda su doznake bile dobrodošle za albansku ekonomiju ${ }^{89}$ neadekvatnost finansijskih institucija i nedostatak tržišnog iskustva među narodom, uticao je da doznake, dugoročno gledano, proizvedu sasvim drugačije posledice od onih prvobitno očekivanih. Ta neadekvatnost sadržana je u slabosti platnog sistema banaka u Albaniji, zbog čega je vladalo veliko nepovjerenje $u$ iste. Takođe, veliki procenat nenaplaćenih pozajmica uticao je na povećanu striktnost Banke Albanije prema drugim bankama u smislu sužavanja prostora njihovih kreditnih aktivnosti. ${ }^{90}$ Takav položaj banaka nije mogao ispratiti potražnju klijenata i time je direktno proizveo "cvjetanje“ neformalnog kreditnog tržišta. Isprva, pored običnih pozajmica među stanovništvom, akumulirani kapital putem doznaka pozajmljivao se za razvoj privatnog sektora, ali i za finansiranje raznoraznih aktivnosti posredstvom SR Jugoslavije i sankcija kojima je ona bila izložena, razumije se pod značajnijim kamatnim stopama (pet i šest procenata). I u takvim djelatnostima postojali su primjeri piramidalnih šema, međutim zanemarljivih u odnosu na kasnije tokom 1996. godine. U vezi s tim, nekoliko događaja posebno je važno u shvatanju te razlike. Prvi jeste ukidanje sankcija SRJ (decembar 1995. godine) i nestanak svega što je vanredno međugranično stanje donosilo (dozvoljavalo), zatim parlamentarni izbori (maj 1996. godine), ${ }^{91}$ pred i postizborni kontekst i prateći lokalni izbori (oktobar 1996.

${ }^{86}$ Doznake su pretežno stizale od niskoplaćenih i neprijavljenih zaposlenja albanskih iseljenika u poljoprivredi, građevini ili uslužnoj industriji u Italiji i Grčkoj. Vidjeti: Smoki Musaraj, "Tales from Albarado: The Materiality of Pyramid Schemes in Postsocialist Albania", Cultural Anthropology, vol. 26, no. 1, 2011, p. 93.

${ }^{87}$ Ibid., p. 93.

${ }^{88}$ Ibid., p. 93.

${ }^{89}$ Procjene ukazuju da su doznake na godišnjem nivou iznosile oko 300 miliona dolara. Time je do 1996. godine okvirno milijardu dolara stiglo u zemlju, dok su iste činile oko 12 \% ukupnog BDP-a u Albaniji. Chris Jarvis, "The Rise and Fall of the Pyramid Schemes in Albania", IMF Staff Papers, vol. 47, no. 1, 2000, p. 6.

${ }^{90}$ Podaci sa kraja 1994. godine, govore da je 27\% pozajmica počevši od jula 1992. godine bilo nenaplativo, dok je godinu dana kasnije u 2/3 državnih banaka preko $50 \%$ pozajmica probilo vremenske rokove. Ibid., p. 3.

${ }^{91}$ Posebno zanimljiv jeste predizborni slogan Demokratske partije: „Sa nama svako dobija" (Me ne fitojnë të gjihtë), aludirajući time i na dobitke iz piramidalnih šema, pored onih (očekivanih) izbornih. Vidjeti: Smoki Musaraj, “Tales from Albarado: The Materiality of Pyramid Schemes in Postsocialist Albania", op. cit., p. 101. 
godine). S obzirom na karakter izborne pobijede demokrata i očekivanih lokalnih izbora, vlastima nije bilo u interesu da sumnjičavost piramidalnih šema (koje su se aktivnije pojavljivale sa približavanjem parlamentarnih izbora), ${ }^{92}$ ostane nepromijenjena ili još gore bude pojačana. ${ }^{93}$ Shodno tome, kompanije koje su se bavile ovakvim šemama (VEFA, Đalica (Gjallica), Kamberi) povećale su svoje kamatne stope na 6-10\%. Njima su se pridružile postojeće Džaferi (Xhafferi), Populi (Populli) i novoosnovana Sude, od kojih je poslednja nudila mnogo veće kamatne stope (od 12 do 19\%). Takva odluka imala je odraz kotrljajuće sniježne grudve, budući da su obećani povraćaji privlačili nezamisliv broj depozita. Samim tim, u drugoj polovini 1996. godine ponovnim povećavanjem kamatnih stopa (u nekim slučajevima i do $50 \%$ ) piramidalne kompanije su se utrkivale u pridobijanju depozita. Sagledavanja radi, neposredno prije urušavanja šema u novembru, više od milion i šest stotina hiljada građana Albanije bilo je uključeno u ove aktivnosti ukupne vrijednosti oko 1,2 milijarde dolara. S obzirom na ove brojke i neminovnu propast piramidalnih šema, ubrzo su počela pristizati međunarodna upozorenja od MMF-a i Svjetske banke. Kada je riječ o 1996. godini, tačnije u julu i junu kroz MMF-ov pregled monetarnih podataka Albanije primijećene su prve intimacije negativnih efekata piramidalnih šema na bankarski sistem u državi. ${ }^{94} \mathrm{Zbog}$ toga je nakon pregleda, upućeno pismo upozorenja ističući neophodnost preventivne akcije praćeno zvaničnim upozorenjem u oktobru. Za razliku od prethodnog međusobnog oslanjanja MMF-a i Albanije u podršci (pravdanju) svojih djelatnosti, ovog puta Beriša je stao na stranu piramidalnih kompanija. Odgovor se zasnivao na privatnom karakteru kompanija koje su primjer ekonomske transformacije bivšeg socijalističkog društva i važni investitori u vrijednim ekonomskim sektorima. Takođe, date depozite Beriša je nazvao albanskim novcem oslikavajući time podršku koja je postojala među albanskim društvom za nastavak funkcionisanja ovih šema. ${ }^{95}$ Ipak mjehur stvoren neracionalnim ponašanjem imao je svoj rok trajanja - 19. novembar, kada Sude nije više bio u stanju da isplaćuje dobitke i čime je kolaps otpočeo. ${ }^{96}$

${ }^{92} \mathrm{U}$ Albaniji ipak nije postojalo jednoglasje povodom piramidalnih šema. Prema tadašnjim zakonima, nijedna druga pravna lica osim banaka se nisu mogla baviti kreditnim aktivnostima. Tako su piramidalne kompanije kršile zakon budući da nisu imale dozvolu, međutim taj nedostatak u praksi nije imao pravne posledice, $s$ obzirom na to da su iste prožele veliki dio albanskog društva. Time je Banka Albanije bila u podređenoj poziciji u sprovođenju pravnih akata.

${ }^{93}$ Chris Jarvis, "The Rise and Fall of the Pyramid Schemes in Albania", op. cit., p. 9.

${ }^{94}$ Ibid., pp. 13-14.

95 Vidjeti: Smoki Musaraj, “Tales from Albarado: The Materiality of Pyramid Schemes in Postsocialist Albania", op. cit., p. 102.

${ }^{96}$ Chris Jarvis, "The Rise and Fall of the Pyramid Schemes in Albania", op. cit., p. 14. 
Pokušaji da se održi dotok depozita smanjenjem kamatnih stopa na pet procenata na mjesečnom nivou nisu uspijeli. Slabljenjem i konačnim iščeznućem povjerenja naroda u piramidalne kompanije, pomenute su već sredinom i krajem januara 1997. godine bile prinuđene na bankrot. Proglašavanjem bankrota, prouzrokovani su veliki protesti protiv vlade i njenih institucija, osobito na jugu države u Valoni, Lušnju (Lushnjë) i u pojedinim naseljima Tirane. ${ }^{97}$ Odmah po krahu firmi, vlada je objavila da depozitarima njihovi ulozi neće biti vraćeni iz budžeta, ali određena kontrola štete sprovedena je kroz zamrzavanje bankarskih računa Džaferi i Populi kompanija, na kojima se nalazilo oko 250 miliona dolara novca koji je vraćen stanovništvu. ${ }^{98}$ Takav potez proizveo je još veću negativnu reakciju protestanata, s obzirom da je time, kako se smatralo, potvrđena umješanost vlade u piramidalnim šemama. Nepovratnog odraza na agresivnost protesta imala je propast najobimnije piramidalne kompanije Đalica, sa sjedištem $u$ Valoni. Dugovanja koja su na dan proglašenja bankrota iznosila čak 343 miliona dolara ${ }^{99}$ rapidno su uvećala proteste, koji su se proširili i u drugim gradovima na jugu države, regiona najviše pogođenog urušavanjem piramidalnih šema. Ozlojeđenost protestanata iz ovog grada, podržanih od strane studenata, su tokom februara rezultirala poharom obližnje vojne baze i u otvorenoj oružanoj konfrontaciji sa predstavništvima centralne vlasti, najprije sa policijom i SHIK-om. Suočena sa brojnošću oružanih grupa, vlada u Tirani je krajem februara, odnosno početkom marta mjeseca, izgubila kontrolu nad Valonom, dok se talas pobune iz Valone gotovo preko noći prenio na ostatak juga u Sarandu, Đirokastru i Himaru. ${ }^{100}$ Napori centralne

${ }^{97}$ U Lušnju su 24. januara zapaljene i opljačkane lokalna skupština i policijska stanica. Sledećeg dana u cilju smirivanja situacije grad je posjetio tadašnji ministar spoljnih poslova Tritan Šehu, koji je prilikom susreta sa protestantima na gradskom stadionu postao njihov talac. Istog dana u večernjim satima specijalne snage su intervenisale i izbavile ministra, dok su do jutra sve državne institucije, izuzev predstavništva ministarstva unutrašnjih poslova, bile opljačkane i uništene. Događaji u Lušnju se nerijetko uzimaju kao datum početka pobune u Albaniji.

${ }^{98}$ Chris Jarvis, "The Rise and Fall of the Pyramid Schemes in Albania", op. cit., p. 16. ${ }^{99}$ Ibid., p. 11.

${ }^{100}$ Pored toga što je jug Albanije bio najviše pogođen slomom piramidalnih šema, činjenica da Demokratska partija nije uživala prevladavajuće povjerenje u pomenutom dijelu zemlje imala je odlučujući uticaj na početak i munjevito uvećanje pobune. Takođe, tradicionalnom podjelom u Albaniji na demokratski sjever i socijalistički jug uticala je da je u drugom tokom Hladnog rata usled blizine Italiji i prohodnosti kopnene granice sa Grčkom bilo stacionirano osjetno više vojske. Ipak, više puta pominjane reforme zahvatile su i vojni sektor, koji je doživio dramatično smanjenje osoblja, pri čemu su nekada ponosni oficiri bili prinuđeni na život u siromaštvu. Osim toga, dobar dio vojnog osoblja bio je uključen u piramidalne šeme kao posrednik ili investitor. Samim time kada se stepen nezadovoljstva povećao ukazala se prilika i oni su je iskoristili. Vidjeti: Smoki Musaraj, "Tales from 
vlade ka povratku vlasti u pomenutim gradovima bivaju osujećeni, kako zbog dezertiranja vojnih i policijskih snaga ${ }^{101}$ tako zbog brojnosti oružanih grupa, čime je Albanija faktički zapala u stanje građanskog rata. Povrh ovog, slom centralne vlasti na jugu države omogućio je pustošenje tamošnjih vojnih baza, što je navelo Berišu da dozvoli otvaranje vojnih magacina na sjeveru u cilju osnaženja svog uporišta. ${ }^{102}$ Takva odluka dovela je do sunovrata vladinih snaga pred naoružanim stanovništvom (od kojih su dobran broj činile Berišine pristalice), čime je izuzev pojedinih puteva u centralnom dijelu države, odnosno naselja u Tirani, ostatak Albanije bio izvan vladine kontrole. ${ }^{103}$ Time se nad Albanijom nadvila opasnost regionalnog sukoba (jug-sjever), budući da je funkcija vršenja vlasti na jugu pripala pobunjeničkim "komitetima spasenja" - mješavini lokalnih kriminalnih bandi, članova Socijalističke partije i bivšeg Sigurimi-ja, sa ciljem Berišinog odlaska, ${ }^{104}$ naspram bandi sjevera države tradicionalnog uporišta Demokrata. U međuvremenu, dalja deoba dešava se između predsjednika i novopostavljenog premijera Baškima Fina (Bahskim Fino), gdje su se u sveopštem metežu i propasti centralne vlasti iskristalisala četiri pseudocentra moći: predsjednik Beriša i njegovi podržavaoci većinom članovi SHIK-a sa sjevera, premijer Fino sa preostalim pripadnicima policije, pobunjenički komiteti spasenja na jugu i lokalni naoružani zapovjednici širom države. ${ }^{105}$

Albarado: The Materiality of Pyramid Schemes in Postsocialist Albania", op. cit., p. 100. James Pettifer \& Miranda Vickers, The Albanian Question, Reshaping the Balkans, Bloomsbury Publishing (I.B. Tauris), 2007, London, p. 56.

${ }^{101} \mathrm{Od}$ mnogobrojnih primjera dezerterstva, upečatljiv je slučaj Argona Dajcija i Ardijana Elezija, pilota Albanskog ratnog vazduhoplovstva, koji su odbili naređenje dejstvovanja po pobunjenicima na jugu države i umjesto toga su sa svojim MiG-15 avionima sletjeli u Galatina vojnu bazu, blizu Lećea u Italiji, gdje su i zatražili politički azil. Vlada Albanije je demantovala izdavanje takvog naređenja. Siobhan Darrow, "Albania's army pushes south to crush uprising", CNN, 5. mart 1997.

${ }^{102} \mathrm{O}$ enormnoj količini naoružanja u Albaniji, svjedoči i pomoć SAD Albaniji za uništenje istog u sklopu Nunn-Lugar Sporazuma. Albanija je bila jedina država izvan SSSR-a koja je primila takvu vrstu pomoći od SAD 2004. godine.

${ }^{103}$ Zanimljiva je reakcija tadašnjeg ministra pravde Spartaka Đele na propast centralne vlasti: „Sve državne strukture su propale. U ovom trenutku smo u prirodnom stanju ukoliko poznajete svog Hobsa“. Bernd J. Fischer, "Albania since 1989: The Hoxhaist Legacy", op. cit., p. 487.

${ }^{104}$ Nedugo potom osnivanja, lokalni komiteti na jugu ujedinjuju se u Nacionalni komitet sa imperativom ostavke predsjednika. Može se reći da su predstavnici prethodnog režima uključujući i Fatosa Nana, iskoristili vakuum centralne uprave i usmjerili pobunu na jugu zemlje isključivo protiv Beriše u cilju njihovog preuzimanja vlasti.

${ }^{105}$ James Pettifer \& Miranda Vickers, The Albanian Question, Reshaping the Balkans, op. cit., p. 54. Tipičan primjer takvih zapovjednika bio je Zani Čauši, koji je pre pobune bio omanji kriminalac, da bi u jeku priprema Berišine ofanzive sa rijeke Vijuše 
Premda je nastala situacija prijetila strahovitim posledicama, jedinstveni stav međunarodne zajednice nije postojao. Pojedinačni naumi država vezanih za Albaniju sprečavali su stvaranje zajedničke koalicije za djelovanje. Na jednoj strani, Italija i Grčka insistirale su na bržoj reakciji, budući da je val albanskih iseljenika već bio u poodmakloj fazi. Sa njima su se unutar EU složile Francuska i Holandija, za razliku od Njemačke i Velike Britanije koje su sa SAD (nevoljnu) humanitarnu intervenciju uslovljavale Berišinom ostavkom. ${ }^{106}$ Podijeljenost EU postavila je OEBS na prvom mjestu, čiji je zvanični predstavnik Franc Vranicki (Franz Vranitzky) činio značajne napore u sprečavanju potpunog unutrašnjeg sukoba u Albaniji. Djelimični napredak postignut je 9. marta, kada je predstavnikovim posredovanjem imenovana nova Vlada nacionalnog pomirenja pod Baškimom Finom i još važnije, zakazani su novi parlamentarni izbori juna iste godine. ${ }^{107}$ Iako je uspostavljena partijski heterogena vlada, predvođena socijalistom, ista nije mogla spriječiti dalje naviranje pobune, odnosno posrtanje državnih kapaciteta, stoga je međunarodna intervencija izgledala kao jedina opcija za izbjegavanje građanskog rata. Prethodno pomenuti razlozi podstakli su hitru reakciju Italije i Grčke, koje su zajedno sa Turskom, Austrijom, Danskom, Rumunijom i Španijom između 24. i 28. marta oformile OEBS koaliciju i na osnovu UN rezolucija 1101 i 1114 pokrenule operaciju Alba. ${ }^{108}$ Uprkos tome što je mandat misije bio sadržan u stvaranju sigurnog okruženja za humanitarnu i civilnu OEBS pomoć u praćenju izbora, ${ }^{109}$ prisustvo međunarodnih snaga imalo je posrednog efekta na posustajanje otvorenih oružanih sukoba između pseudo-centara moći. Ipak, opadanje intenziteta sukoba nije podrazumijevalo predizbornu kampanju bez ograničenja. Teritorijalna polarizacija Albanije, sa rijetkim izuzecima, ${ }^{110}$

(privremenoj granici između vlade i pobunjenika na jugu) na Valonu, Čauši formirao paramilitarne snage za odbranu grada. Osvajanjem vojnih magacina $u$ gradu, Zani je sakupio veliku količinu naoružanja, nakon čega je zbog uspješne opstrukcije režimskih planova za vojno suzbijanje juga, uživao osobit ugled širom južne i središnje Albanije. Ibid., p. 57.

${ }^{106}$ Umjesto humanitarne intervencije, EU je na konferenciji u Apeldornu 15. i 16. marta ponudila humanitarnu pomoć, međutim tek kada bi stanje na terenu bilo dovoljno bezbjedno da podrži takav projekat. Vidjeti: Paolo Tripodi, "Operation Alba: A Necessary and Successful Preventive Deployment", International Peacekeeping, vol. 9, no. 4, 2002, p. 96.

${ }^{107}$ Hugh Miall, "The OSCE role in Albania: a success for conflict prevention”, Helsinki Monitor, vol. 8, no. 4, 1997, p. 81.

${ }^{108}$ Ibid., pp. 81-82.

${ }^{109}$ Ibid., pp. 81-82.

${ }^{110}$ Poput predizbornog odlaska Beriše u grad Fjer na jugu i Nanove posjete Kukešu na sjeveru zemlje. James Pettifer \& Miranda Vickers, The Albanian Question, Reshaping the Balkans, op. cit., pp. 79, 81. 
„rezervisala“ je mnogobrojne djelove zemlje za predizbornu kampanju određenih političkih partija. Takođe, u sveukupnom karambolu, u proljeće 1997. godine, u Albaniju je s ciljem obnove monarhije stigao Leka I, sin nekadašnjeg albanskog kralja Zog-ua I. Iako je Leka okupio značajan broj pristalica, cjelokupni uslovi političkog spektra u Albaniji nisu ohrabrivali promjenu političkog uređenja. ${ }^{111}$ Međutim, promjena koja je bila prihvatljiva jeste Berišin odlazak. Stoga je postojala izrazita međunarodna potreba da se delikatni izborni dan u Albaniji proglasi prihvatljivim. ${ }^{112}$ Takođe, na domaćem tlu tekovine Berišinog mandata podstakle su i prožele Albance snažnim antagonizmom prema svom predsjedniku, pri čemu je sunovrat piramidalnih šema bio samo inicijator pokazivanja tog rasprostranjenog nezadovoljstva i ogorčenja. Bitno je naglasiti da je takva "anti-Beriša“ osjećanja, socijalistička partija predvođena Nanom uspjela kanalisati u svoju podršku i odnijeti izbornu pobjedu. ${ }^{113}$

Ponovno osvajanje vlasti ispostavilo je veliki izazov, budući da se zemlja nalazila u katastrofalnoj situaciji. Prvenstveno u smislu kontrole državne teritorije, gdje "lokalna vlast" nije bila spremna odreći se od svog "pobunjeničkog dostignuća“. Iako je izostanak uprave nad određenom teritorijom predstavljalo ozbiljan problem, nova vlast se istodobno morala pozabaviti kadrovima njene prethodnice, od kojih su mnogi bili lojalni Beriši. Premda je slom piramidalnih šema pokrenuo mnogobrojne događaje

${ }^{111}$ Uporedo sa parlamentarnim izborima održavao se referendum za obnovu monarhije u Albaniji. Nešto više od 904 hiljade glasova bilo je protiv (66,7\%), naspram 450 hiljada (33,3\%), koliko je bilo za promjenu društveno-političkog uređenja države. Prestolonaslednik ove rezultate nije prihvatio, nakon čega je sa svojim pristalicama i ministrom „kraljevskog dvora“ Abedinom Mulosamanijem pokrenuo proteste u Tirani, tvrdeći da je preko $60 \%$ izašlih glasalo za obnovu monarhije u Albaniji. Ipak, glasine o životnoj opasnosti sina nekadašnjeg kralja Albanaca, uticale su da Leka I već 12. jula 1997. godine napusti Albaniju i vrati se u Johanesburg gdje je i rođen. Ibid., p. 85.

112 Zaključci OEBS-a povodom izbora: „Kancelarija za demokratske institucije i ljudska prava zaključila je da se albanski parlamentarni izbori 1997. godine mogu ocijeniti kao prihvatljivi, s obzirom na preovlađujuće okolnosti u državi. Ovaj izborni proces se mora posmatrati u kontekstu procesa rešavanja sukoba nakon teške političke krize koja je prethodila i koja je imala neposredne posledice po izborne standarde." Final Report on Parliamentary Elections in Albania, 29 June 1997, 1997, Internet, https://www.osce.org/files/f/documents/3/8/14029.pdf , 16/01/2021, p. 4.

${ }^{113}$ Nakon izbora, socijalisti su zajedno sa svojim koalicionim partnerima imali 118 poslaničkih mjesta u parlamentu naspram 24 koliko su Demokrate posjedovale. Takođe, formalno preuzimanje položaja predsjednika izvršeno je tek 23 . jula, kada je Beriša podnio ostavku na pomenutu poziciju, pri čemu je i dalje osporavao rezultate, međutim prihvatajući ostavku kao "političko rešenje“ za krizu. Naslijedio ga je Redžep Majdani (Rexhep Meidani) iz Socijalističke partije. Vidjeti: James Pettifer \& Miranda Vickers, The Albanian Question, Reshaping the Balkans, op. cit., pp. 83, 85. 
tokom 1997. godine, posledice neće imati istovjetni odraz na dalja dešavanja u državi. Porast intenziteta krize na Kosovu, u paru sa nemogućnostima vršenja uprave Tirane nad sjevernim dijelom zemlje, uticaće na ponovnu borbu za preuzimanje vlasti u zemlji tokom septembra 1998. godine. Ipak, umjesto piramidalnih šema, suštinskog uticaja imaće ciljevi sa obje strane granice uspostavljene 1912. godine, koji će stvoriti nova, nesvakidašnja savezništva među albanskim narodom i time u dogledno vrijeme odrediti postavku stvari u Albaniji. ${ }^{114}$

\section{Zaključak}

Premda ovaj rad istražuje razdoblje s kraja XX vijeka, pojam koji obilježava suštinu njegove teme, i koji je konstantan u albanskom društvu mnogo prije predmetnog perioda (ali i u njegovom okruženju), jeste ekskluzivitet skupina koje u datom trenutku posjeduju pozicije vlasti, moći i uticaja. Neposredna posledica toga jeste isključenost drugih grupa koje su sastavni dio tog društva, a koje su prethodno bile u takvoj poziciji. Iz takvog stanja proizilaze naizmjenični procesi smjenjivanja tih skupina na položaje uprave $u$ određenom društvu, uz rijetke primjere složenije međusobne interakcije i odustajanja od upotrebe svih raspoloživih kapaciteta za ostanak na tim položajima. "Nasljeđe“ tih sistema jesu prikriveni osjećaji nezadovoljstva u slojevima društva odgovarajućih grupa koje su $\mathrm{u}$ momentu van odlučujućih zaduženja u državi. Ti osjećaji će se ispoljiti samo u masovnim oblicima i gotovo uvijek će imati krajnost za svoju osnovu. Isto tako, ukoliko je društvo karakteristično po mnogobrojnim razlikama u domenu vjeroispovijesti, jezika i uopšte mentaliteta, po pravilu je da će one u bivšim komunističkim državama Evrope još jednom doći do izražaja, te da će njihov odraz upravo kao posledica komnuzima i naizmjenične smjene vlasti biti još veći. Konkretno, uzimajući u obzir predizbornu situaciju 19911992. i 1996-1997. u Albaniji, upečatljiva je obrnuta proporcionalnost između tih izbornih procesa, gdje mogući produžetak vladavine postojeće vlasti možda ne bi bio poželjan ishod po albansko društvo. Međutim, ovo istraživanje ne bi bilo cjelovito ako bi analiza tog procesa smjene izostavila međunarodnu ulogu, odnosno zadovoljenje međunarodnih interesa.

\section{Bibliografija}

Alia, Ramiz, Une, Ramiz AIia deshmoj per historine, Zeri, Priština, 1992. Bezemer, J. Dirk, "Post-socialist financial fragility: the case of Albania", Cambridge Journal of Economics, vol. 25. no. 1, 2001, pp, . 1-23.

${ }^{114}$ Vidjeti: Malte Olševski, Rat za Kosovo, Novi boj Srbije na Kosovu (Der Krieg um Kosovo, 60 Serbiens neue Sclacht am Amselfeld), Nidda i Prometej, Novi Sad, 1999, pp. 36-37. 
Bideleux, Robbert, Jeffries, Ian, The Balkans, a post-Communist history, Routledge, New York, 2007.

Copani, Adem \& Sray, John, Partnership for Peace and New Dimensions of Albania's Security Posture, 1996, Internet, https://community.apan.org/ wg/tradoc-g2/fmso/m/fmso-monographs/244584, 05/12/2020.

Darrow, Siobhan, "Albania's army pushes south to crush uprising", CNN, 5. mart 1997.

Domachowska, Agata, "Albanian Migration as a Post-Totalitarian Legacy", Migration Studies - Review of Polish Diaspora, vol. 45, no. 2, 2019, pp. 87100.

Ekiert, Grzegorz, Kubik, Jan, Vachudova \& Milada Anna, "Democracy in the Post-Communist World: An Unending Quest?", East European Politics and Societies, vol. 21, no. 1, 2007, pp. 7-30.

Elbasani, Arolda, Religion and Democratization in Post-Communist Albania: Is it Possible to Be Islamic, Democratic and European at the Same Time?, 2010, Internet, https://www.researchgate.net/publication/228161084_ Religion_and_Democratization_in_PostCommunist_Albania_Is_it_Poss ible_to_Be_Islamic_Democratic_and_European_at_the_Same_Time , 27/10/2020.

Fidrmuc, Jan, Economic reform, democracy and growth during post-communist transition, Internet, https://core.ac.uk/download/pdf/7056986.pdf , 2001, 04/01/2020.

Final Report on Parliamentary Elections in Albania, 29 June 1997, 1997, Internet, https://www.osce.org/files/f/documents/3/8/14029.pdf 16/01/2021.

Fischer, J. Bernd, “Albania since 1989: The Hoxhaist Legacy”, in: Sabrina P. Ramet (ed.), Central and Southeast European Politics since 1989, Cambridge University Press, New York, 2010, pp. 477-506.

Greece trade balance, exports and imports by country and region 1996, 1996, Internet, https://wits.worldbank.org/CountryProfile/en/Country/ GRC/Year/1996/TradeFlow/EXPIMP , 12/12/2020.

Hendrickson, Ryan, "Albania and NATO: Regional Security and Selective Intervention", Security Dialogue, vol. 30, no. 1, 1999, pp. 109-116.

Huntington, P. Samuel, "Democracy's Third Wave", Journal of Democracy, vol. 2, no. 2, 1991, pp. 12-34.

IRI Observation Report on the Albanian Parliamentary Elections of May 26, 1996, 1996, Internet, https://www.iri.org/sites/default/files/Albania's\%20 1996\%20Parliamentary\%20Elections.pdf , 16/01/2020.

Italy trade balance, exports and imports by country 1996, 1996, Internet, https://wits.worldbank.org/CountryProfile/en/Country/ITA/Year/ 1996/TradeFlow/Export/Partner/by-country , 05/12/2020. 
Jarvis, Chris, "The Rise and Fall of the Pyramid Schemes in Albania", IMF Staff Papers, vol. 47, no. 1, 2000, pp. 1-29.

Jović, Dejan, "Problems of early post-communist transition theory: from transition from to transition to", Politička misao časopis za politologiju, vol. 47, no. 5, 2010, pp. 44-68.

Kajsiu, Blendi, "Down with Politics! The Crisis of Representation in PostCommunist Albania", East European Politics and Societies, vol. 24, no. 5, 2010, pp. 229-253.

Lani, Remzi, Schmidt, Fabian, "Albanian foreign policy between geography and history", The International Spectator: Italian Journal of International Affairs, vol. 33, no. 2, 1998, pp. 79-103.

Law Nr. 8001 on Genocide and Crimes against Humanity Committed in Albania during Communist Rule for Political, Ideological and Religious Motives, 2018, Internet, http://www.derechos.org/intlaw/doc/alb2.html, 24/12/2020.

Lusho, Sherif \& Papa, Dhimitër, Land Fragmentation and Consolidation in Albania, 1998, Internet, https:// minds.wisconsin.edu/bitstream/handle /1793/21965/50_wp25.pdf?sequence=1\&isAllowed=y , 23/11/2020.

Miall, Hugh, "The OSCE role in Albania: a success for conflict prevention", Helsinki Monitor, vol. 8, no. 4, 1997, pp. 74-85.

Musaraj, Smoki, "Tales from Albarado: The Materiality of Pyramid Schemes in Postsocialist Albania", Cultural Anthropology, vol. 26, vo.1, 2011, pp. 84-110.

Muço, Marta, Economic Transition in Albania: Political Constraints and Mentality Barriers, 1997, Internet, https://www.nato.int/acad/fellow/ 95-97/muco.pdf , 14/12/2020.

Olševski, Malte, Rat za Kosovo, Novi boj Srbije na Kosovu (Der Krieg um Kosovo, Serbiens neue Sclacht am Amselfeld), Nidda i Prometej, Novi Sad, 1999.

Pettifer, James, Vickers, Miranda, The Albanian Question, Reshaping the Balkans, Bloomsbury Publishing (I.B. Tauris), 2007, London.

Przeworski, Adam, Democracy and the market: Political and economic reforms in Eastern Europe and Latin America, Cambridge University Press, Cambridge, 1991.

Stone, W. Randall, Lending credibility: The International Monetary Fund and the post-communist transition, Princeton University Press, Princeton, 2012.

Tarifa, Fatos, "Albania's Road from Communism: Political and Social Change, 1990-1993", Development and Change, vol. 26, no. 1, 1995, pp. 133-162.

The Constitution of the People's Socialist Republic of Albania, Internet, 2005, http:/ / bjoerna.dk/dokumentation/Albanian-Constitution-1976.htm , $62 \quad 20 / 10 / 2020$. 
Tripodi, Paolo, “Operation Alba: A Necessary and Successful Preventive Deployment", International Peacekeeping, vol. 9, no. 4, 2002, pp. 89-104.

Vladisavljević, Nebojša, "Revolutionary Origins of Political Regimes and Trajectories of Popular Mobilization in the Late Communist Period", Nationalities Papers, vol. 47, no. 4, 2019, pp. 545-561.

Vullnetari, Julie, Albanian Migration and Development: State of the Art Review, IMISCOE, Amsterdam, 2007.

Vullnetari, Julie, Albania on the Move, Links between Internal and International Migration, Amsterdam University Press, Amsterdam, 2012.

Waal de, Clarissa, "From Laissez-Faire to Anarchy in Post-Communist Albania", The Cambridge Journal of Anthropology, vol. 20, no. 3, 1998, pp. 21-44.

Welsh, A. Helga, "Political Transition Processes in Central and Eastern Europe", Comparative Politics, vol. 26, no. 4, 1994, pp. 379-394.

\title{
SKA SHTETI, SKA LIGJ! (NO STATE, NO LAW!) INTERNAL POLITICAL CHALLENGES AND TRANSITIONAL DIFFICULTIES IN ALBANIA 1990-1997
}

\begin{abstract}
The study investigates the impact of post-Cold War pervasive control measures on Albanians' reactions to the collapse of such a system and its consequences. It is also necessary to consider Albanian national diversity, the history of the submission of central governments, and the intentions of the communist government in creating a strong government and an integrated Albanian nation. As a result, the research question is: did the lack of democratic experience among post-socialist leaders, combined with (too) rapid social changes, encourage the return of Albanian national differences and the challenge to the authority of central administrations? The qualitative methods of analysis show that the sinking of a highly rigorous system was accompanied by extremes. Likewise, the rapid transition to an organization where non-established government officials have a much smaller regulatory role is more than a fertile ground for restoring internal national diversity and thus rejecting the principles of state organization.

Keywords: Albania, transition, Sali Berisha, elections, pyramid schemes, particularism.
\end{abstract}

